\title{
Silicate and oxide inclusion characteristics and infra-red absorption analysis of diamonds from the Klipspringer kimberlites, South Africa
}

\author{
K.J. Westerlund \\ Department of Geological Sciences, University of Cape Town, Private Bag, Rondebosch 7701, South Africa \\ e-mail: kjw@geology.uct.ac.za \\ J.J. Gurney \\ Department of Geological Sciences, University of Cape Town, Private Bag, Rondebosch 7701, South Africa \\ e-mail: jig@geology.uct.ac.za
}

O 2004 Geological Society of South Africa

\begin{abstract}
The diamonds associated with the 148 Ma Group II Klipspringer kimberlite dyke system emplaced on the Thabazimbi-Murchison Lineament are predominantly of eclogitic origin, and in a parallel study have been demonstrated to have a late Archean origin. Fourier Transform Infra-Red (FTIR) analysis of diamond plates demonstrates complex intergrowth of $\mathrm{N}$-rich and $\mathrm{N}$-poor diamond. Two groups of diamonds occurring in both the Main Fissure and the Sugarbird Blow have been recognised with time averaged mantle residence temperatures (MRT) based on nitrogen aggregation of approximately $1090^{\circ} \mathrm{C}$ (low- $\mathrm{T}$ ) and $1170^{\circ} \mathrm{C}$ (high-T) respectively. In some cases a core of high-T diamond is enclosed within an envelope of low- $\mathrm{T}$ diamond. At Marsfontein, a third diamond population with an MRT $<1070^{\circ} \mathrm{C}$ is present that has not been recorded in diamonds from the Main Fissure or the Sugarbird Blow. Observed lamination lines attest to a deformation event having affected most of the high-T diamonds. A correlation between hydrogen and the ratio between nitrogen present in B aggregates and platelet peak intensity suggests that the presence of hydrogen affects the formation of platelets.

Mineral inclusions in the diamonds are predominantly eclogitic (sulfide, garnet, clinopyroxene, kyanite, coesite and rutile). The garnets and clinopyroxenes have a wide range in compositions, extending the worldwide fields for diamond inclusions. The garnets define four groups, one of which is grospyditic and the individual groups display inter-element correlations, which are consistent with magmatic fractionation. The clinopyroxenes include a high aluminium group exhibiting cation site deficiencies ( 7 to $28 \%$ pseudojadeite). Garnets from all four groups, the high aluminium clinopyroxenes and other clinopyroxenes of widely different compositions occur in both the high-T and low- $T$ diamonds. Estimated bulk compositions for diamond bearing eclogite are akin to MOR cumulates from the S.W. Indian Ridge. Thermobarometric estimates for four non-touching garnet-clinopyroxene inclusion pairs in low- $\mathrm{T}$ diamonds are within the range 1152 to $1233^{\circ} \mathrm{C}$ at $50 \mathrm{~kb}$.

It is considered that the high-T Klipspringer diamonds formed in the Archean and underwent deformation followed by the low- $\mathrm{T}$ diamond formation in the host-rock to the high- $\mathrm{T}$ diamonds. The deformation event might have been associated with reactivation of the Thabazimbi-Murchison Lineament. The most likely protolith for the diamonds is subducted oceanic crust in which the inclusions of the low temperature diamonds formed by re-crystallisation of pre-existing minerals. At or shortly after the low-T diamond formation, a cool ( 37 to $39 \mathrm{~mW} / \mathrm{m}$ ?) geotherm was established within this part of the Kaapvaal craton. The diamonds survived the emplacement of the Bushveld Igneous Complex and were subsequently sampled and transported by their host kimberlites in the late Jurassic.
\end{abstract}

\section{Introduction}

Most syngenetic mineral inclusions in diamonds can be assigned to either a peridotitic or an eclogitic paragenesis (e.g. Gurney, 1989). For eclogitic diamonds, which are the focus of this study, an igneous (Boyd and Gurney, 1986; Kesson and Ringwood, 1989) or solidstate metamorphic (Haggerty, 1986) origin has been proposed, as well as metasomatic formation through an open-system fluid-flux into an eclogitic protolith (e.g. Griffin et al., 1988; Deines and Harris, 1995; Taylor et al., 1998; Keller et al., 1999). An increasing amount of evidence points to a genetic link between upper mantle eclogites/eclogitic diamonds and subducted oceanic crust (reviewed by Navon, 1999). The chemical composition and highly fractionated oxygen isotope compositions of upper mantle eclogites may indicate that they represent metamorphosed fragments of oceanic lithosphere and/or oceanic crust with or without associated sediments (e.g. Helmstaedt and Doig, 1975; Jagoutz et al., 1984; MacGregor and Manton, 1986; Helmstaedt and Schulze 1989). In other situations the subducted oceanic crust may be remelted (Hofmann and White, 1982; Ringwood, 1982) or melt incongruently (Ireland et al., 1994; Rudnick, 1995) and subsequently underplate the lithosphere. Eclogitic diamonds are commonly depleted in ${ }^{13} \mathrm{C}$, which may suggest an input from organic carbon (e.g. Frank 1959; Kirkley et al., 1991). An organic input and hydrothermally altered mid-ocean ridge basalt source may also be implied from the observed concurrent depletion in ${ }^{13} \mathrm{C}$ and enrichment in ${ }^{15} \mathrm{~N}$ in eclogitic diamonds and the positive and negative $\mathrm{S}$ isotope excursions of their 


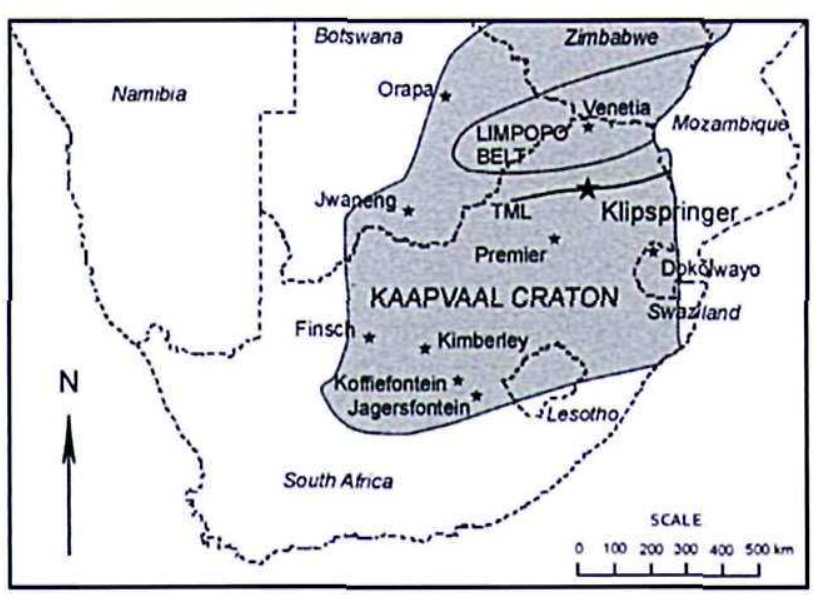

Figure 1. Outline of the Kaapvaal-Zimbabwe craton with the location of the Klipspringer kimberlites. (TML=ThabazimbiMurchison Lineament).

sulfide inclusions (e.g. Eldridge et al., 1991; van Heerden et al., 1995). Further, elevated initial Os isotope compositions in eclogites (Pearson et al., 1995; Menzies et al., 2003) and eclogitic sulfide diamond inclusions (Richardson et al., 2001) have been interpreted to reflect subducted oceanic crust that underplated or was accreted to the lithosphere during craton formation. In contrast, Cartigny et al. (1998a, 1998b) argue against a subducted protolith for eclogitic diamonds and invoke high temperature Rayleigh fractionation to explain the observed covariation of ${ }^{13} \mathrm{C}$ and ${ }^{15} \mathrm{~N}$. Generally accepted models for diamond formation have yet to emerge and it is apparent that further studies on the origin of diamonds are warranted.

The scarcity of diamondiferous mantle xenoliths has limited the study of diamonds in the context of their host rocks and primary growth environment. To elucidate their origin, we commonly have only the diamonds themselves with their atomic and molecular impurities and their fluid and mineral inclusions. Most ages for syngenetic diamond mineral inclusions obtained through studies of radiogenic isotopes range between $\sim 1$ Ga and $\sim 3.5 \mathrm{Ga}$ (e.g. Kramers, 1979; Richardson et al., 1984). This demonstrates that the inclusions were prevented from equilibrating chemically with the surrounding environment by the chemically inert and crystallographically close packed diamond host. Thus, mineral inclusions may provide information about ancient geochemical environments in the mantle and processes of diamond formation. Further, low diffusion rates in diamond allow for the study of ancient impurities in the diamond lattice. This paper presents the infra-red absorption characteristics of the Klipspringer diamonds and the major element composition of their silicate and oxide inclusions and attempts to elucidate the origin of the diamonds and their inclusions.

Geological setting and the Klipspringer lithosphere The Klipspringer kimberlites are located south of the southern margin of the Limpopo mobile bett and close to the Bushveld Igneous Complex in the northeastern part of the Kaapvaal craton (Figure 1). The kimberlites intrude the Thabazimbi-Murchison Lineament (TML), which is a major ENE-WSW striking terrain boundary on the craton. The earliest movements recorded in the TML have been dated at $\sim 2.96 \mathrm{Ga}$ and it may represent the boundary between a Kaapvaal granite-greenstone terrain and the southern margin of the Limpopo mobile belt (Good, 1997; Good and de Wit, 1997). Two major reactivations of the TML occurred at $\sim 2.7 \mathrm{Ga}$ and $\sim 2 \mathrm{Ga}$. Seismic anisotropy data has shown that the lithosphere beneath the TML contains an east-west fast polarisation direction in contrast to the NE-SW direction generally observed for the Kaapvaal craton (Vinnik et al., 1995; Silver et al., 2001). This has been interpreted to mean that formation and/or reactivation of the TML recorded in the crustal rocks can be extrapolated down to the lithospheric mantle. The lithospheric and crustal weakness in the TML may therefore have facilitated the emplacement of the Klipspringer kimberlites.

Diamonds from the Main Fissure, the Sugarbird Blow (which occurs on the Sugarbird Fissure) and the Marsfontein pipe are included in the present study. The Main and Sugarbird Fissures intrude the Malmani dolomites of the Transvaal sequence, which was deposited onto the basement in the early Proterozoic. Both kimberlites are en-echelon dykes, which strike parallel to the TML, and the Sugarbird Fissure is located about 750 metres north of the Main Fissure. The two dykes have been dated at $148 \pm 4 \mathrm{Ma}$ and classify isotopically as Group II kimberlites (Westerlund et al., this volume). The Marsfontein kimberlite intrudes the Meinhardskraal basement granite about 10 kilometres east of the two dykes. Field relations suggest that it constitutes a blow on a continuation of the Main Fissure and th00at it formed contemporaneously with the two dykes.

The lithosphere sampled by the Klipspringer kimberlites is dominated by eclogite and lherzolite, with minor harzburgite and dunite (Westerlund, 2000). Group I eclogites (with elevated $\mathrm{Na}$ contents in the garnets; McCandless and Gurney, 1989) believed to originate from within the diamond stability field are more common than Group II eclogites. Equilibration temperatures for Group I eclogites range up to $1078^{\circ} \mathrm{C}$ and $1119^{\circ} \mathrm{C}$ (using Krogh, 1988) at assumed pressures of 50 kbars and 60 kbars respectively. A geotherm (at $148 \mathrm{Ma}$ ) inferred from eclogite equilibration temperatures corresponds to a conductive model geotherm of $37-39 \mathrm{~mW} / \mathrm{m}^{2}$, which is indicative of a fairly cool lithosphere favourable for diamond preservation.

\section{Analytical techniques FTIR analysis of the diamonds}

Spectra were measured at Anglo American Research Laboratories (currently De Beers GeoScience Centre), Johannesburg, using a Nicolet Magna-IR 760 spectrometer and at the Department of Geology, University of Cape Town, using a Nicolet Magna-IR 560 

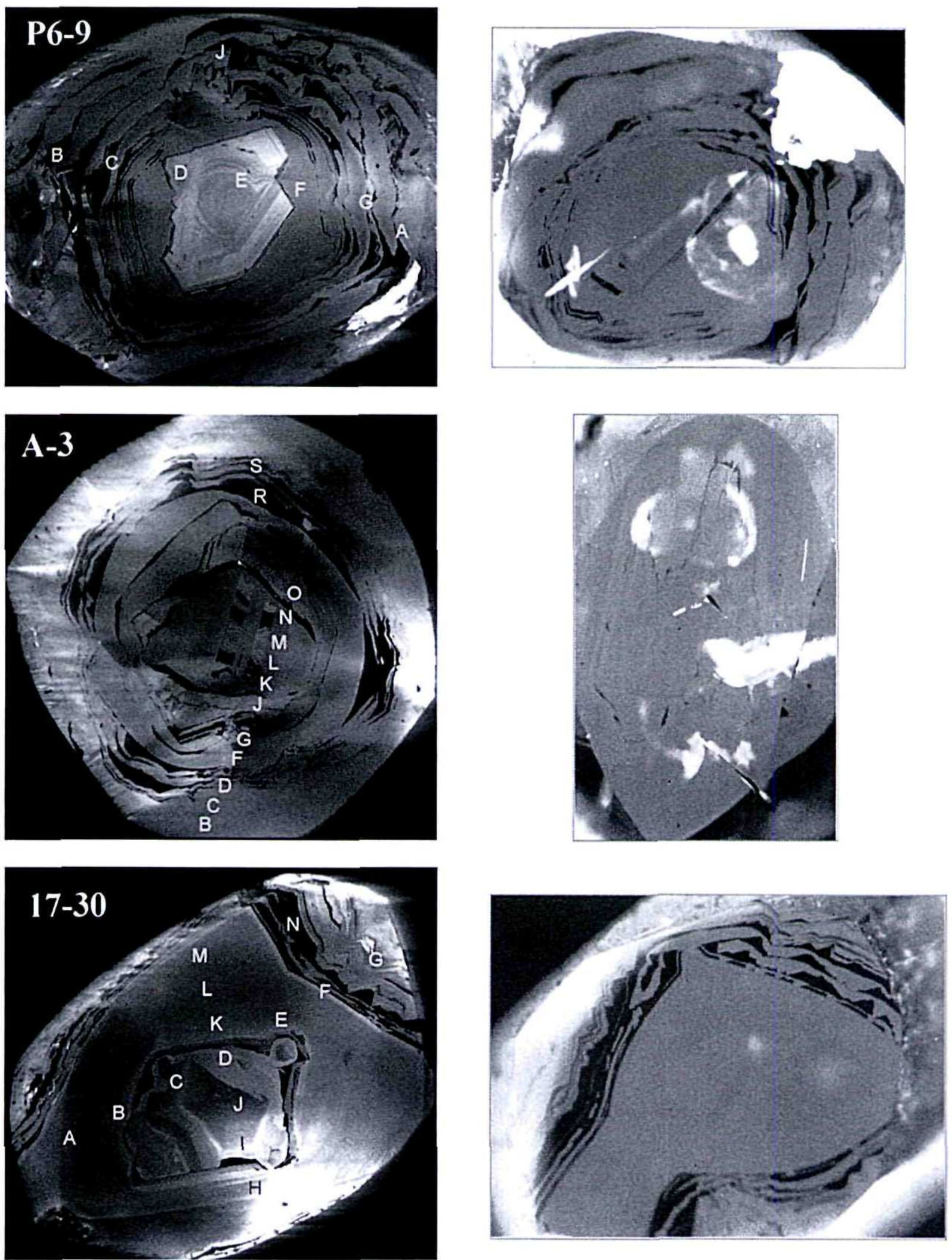

Figure 2. Cathodoluminescence images of polished diamond plates with analysis locations. The plates are $\sim 4 \mathrm{~mm}$ across the longest direction. Front side images (left) were captured with a scanning electron microscope and rear side (right) through an optical microscope attached to a cold cathode cathodoluminescence generator. 
spectrometer. The analyses follow standard procedures and details of the estimation of the nitrogen content and aggregation state as well as mantle residence temperatures are given in Mendelssohn and Milledge (1995). One hundred scans were performed per analysis at a spectral resolution of $8 \mathrm{~cm}^{-1}$.

\section{EMP analysis of diamond inclusion minerals}

The diamonds were examined visually to ensure there were no cracks connecting the inclusions to the exterior of the diamonds before they were liberated from the diamond. The inclusions were analysed at the University of Cape Town using a Cameca Camebax electron microprobe (EMP). Natural standards of similar compositions to the unknowns were used. Counting times were 10 seconds for peaks and backgrounds except for sodium in garnet and potassium in clinopyroxene for which peaks were measured for 30 seconds and backgrounds for 15 seconds.

\section{IR absorption characteristics of the diamonds}

Several studies indicate that the occurrence of nitrogen in diamonds of types Ib (single $\mathrm{N}$ atoms substituting for C), IaA (pairs of $\mathrm{N}$ atoms) and $\mathrm{IaB}$ (four $\mathrm{N}$ atoms arranged around a vacancy) represents a sequence of progressive time- and temperature-dependent aggregation. Type II diamonds are deficient in infra-red active nitrogen (e.g. Clark et al., 1992; Evans, 1992). When the correct activation energy for the aggregation reaction is known, the interdependent parameters of time and temperature of mantle residence for the diamond can be estimated (e.g. Mendelssohn and Milledge, 1995). Temperature is the more sensitive parameter and if the mantle residence time can be roughly estimated (at a scale of hundreds of millions or even a billion years), the time-averaged temperature at which the diamond resided can be constrained. Sulfide bearing eclogitic Klipspringer diamonds have been assigned a formation age of $2554 \pm 150 \mathrm{Ma}$ on the basis of Re-Os systematics (Westerlund et al., this volume). Since the diamonds were removed from the lithosphere by the kimberlites at $\sim 150 \mathrm{Ma}$, some diamonds resided at mantle temperatures for about 2.5 billion years. In the absence of more detailed information, a mantle residence time of 2.5 billion years has been used in the derivation of all temperatures discussed below, and in the interpretation of diamond formation processes in the discussion section. The temperature estimations are based on a value of $7.03 \mathrm{eV}$ for the IaA-IaB activation energy (Taylor et al., 1990).

Platelets are planar features occurring in the cubic planes of the diamond and range in size from $8 \mathrm{~nm}$ up to a few mm (Evans and Qi, 1982). There is a direct correlation between the intensity of the platelet peak and X-ray spike intensity (Sobolev et al., 1968) and thus the platelet peak intensity is an indication of the platelet concentration.

Experimental data on the correlation between hydrogen peak intensities and hydrogen concentrations
Table 1. Fourier-transform infra-red absorptiondata for diamond plates.

\begin{tabular}{|c|c|c|c|c|c|}
\hline \multicolumn{4}{|l|}{ Plate/ } & \multicolumn{2}{|c|}{ Platelet Hydrogen } \\
\hline Analysi & N (ppm) & $\%$ NasB & $\mathrm{T}\left({ }^{\circ} \mathrm{C}\right)$ & $\mu(1365)$ & $\mu(3107)$ \\
\hline P6-9A & 683 & 19.3 & 1093 & 0.365 & 0.480 \\
\hline P6-9B & 373 & 14.3 & 1098 & 0.177 & 0.092 \\
\hline P6-9C & 482 & 23.6 & 1107 & 0.187 & 0.245 \\
\hline P6-9D & 814 & 19.0 & 1088 & 0.310 & 0.870 \\
\hline P6-9E & 900 & 23.0 & 1092 & 0.679 & 0.331 \\
\hline P6-9F & 777 & 19.0 & 1089 & 0.382 & 0.411 \\
\hline P6-9G & 696 & 21.3 & 1095 & 0.359 & 0.552 \\
\hline P6-9J & 744 & 17.2 & 1088 & 0.337 & 0.526 \\
\hline$A-3 B$ & 575 & 15.8 & 1091 & 0.512 & 0.007 \\
\hline$A-3 C$ & 562 & 15.1 & 1091 & 0.474 & 0.012 \\
\hline$A-3 D$ & 562 & 15.1 & 1091 & 0.385 & 0.059 \\
\hline$A-3 E$ & 556 & 15.8 & 1092 & 0.375 & 0.078 \\
\hline$A-3 F$ & 514 & 15.4 & 1093 & 0.285 & 0.153 \\
\hline$A-3 G$ & 520 & 16.5 & 1095 & 0.275 & 0.168 \\
\hline$A-3 J$ & 618 & 15.8 & 1090 & 0.240 & 0.344 \\
\hline$A-3 K$ & 682 & 15.8 & 1087 & 0.291 & 0.369 \\
\hline A-3L & 675 & 15.4 & 1087 & 0.304 & 0.362 \\
\hline A-3M & 703 & 16.5 & 1088 & 0.324 & 0.370 \\
\hline$A-3 N$ & 670 & 15.4 & 1087 & 0.297 & 0.337 \\
\hline $\mathrm{A}-3 \mathrm{O}$ & 587 & 12.8 & 1085 & 0.231 & 0.340 \\
\hline$A-3 R$ & 351 & 13.2 & 1098 & 0.155 & 0.149 \\
\hline A-3S & 465 & 17.3 & 1098 & 0.295 & 0.113 \\
\hline $17-30 \mathrm{~A}$ & 816 & 32.7 & 1105 & 0.095 & 1.963 \\
\hline $17-30 \mathrm{~B}$ & 1154 & 35.3 & 1100 & 0.450 & 1.069 \\
\hline $17-30 \mathrm{C}$ & 1063 & 37.7 & 1104 & 0.718 & 0.484 \\
\hline $17-30 \mathrm{D}$ & 985 & 33.3 & 1101 & 0.335 & 1.145 \\
\hline $17-30 \mathrm{E}$ & 953 & 32.2 & 1101 & 0.239 & 1.415 \\
\hline $17-30 \mathrm{~F}$ & 924 & 30.9 & 1100 & 0.145 & 1.589 \\
\hline $17-30 \mathrm{G}$ & 1012 & 30.6 & 1098 & 0.136 & 2.151 \\
\hline $17-30 \mathrm{H}$ & 805 & 33.8 & 1107 & 0.256 & 1.271 \\
\hline $17-30 I$ & 856 & 34.3 & 1106 & 0.237 & 1.463 \\
\hline $17-30 \mathrm{~J}$ & 958 & 33.8 & 1103 & 0.306 & 1.271 \\
\hline $17-30 \mathrm{~K}$ & 977 & 33.5 & 1102 & 0.339 & 1.016 \\
\hline $17-30 \mathrm{~L}$ & 1024 & 33.0 & 1100 & 0.163 & 1.975 \\
\hline $17-30 \mathrm{M}$ & 799 & 34.6 & 1108 & 0.184 & 1.464 \\
\hline $17-30 \mathrm{~N}$ & 552 & 34.0 & 1116 & 0.213 & 0.491 \\
\hline
\end{tabular}

$\% \mathrm{NasB}$ is the percentage of the total nitrogen, which occurs in $B$ aggregates. The temperatures were estimated assuming a mantle residence time of $2.5 \mathrm{Ga}$.

$\mu=$ absorption coefficient $\left(\mathrm{cm}^{-1}\right)$.

are non-existent. However, hydrogen peak intensities are used in a semi-quantitative way in the present study to evaluate the hydrogen content.

\section{Diamond plates}

IR absorption data for the three analysed diamond plates are given in Table 1 and cathodoluminescence images of the plates (with analysis locations) are shown in Figure 2. In the centre of diamond $P 6-9$ is a discernible rounded seed, which is surrounded (at E on P6-9, Figure 2) by several thin semi-circular zones reminiscent of "agate texture" (Seal, 1965; Bulanova and Griffin, 1995; Zezin et al., 1990). This is succeeded by irregular 


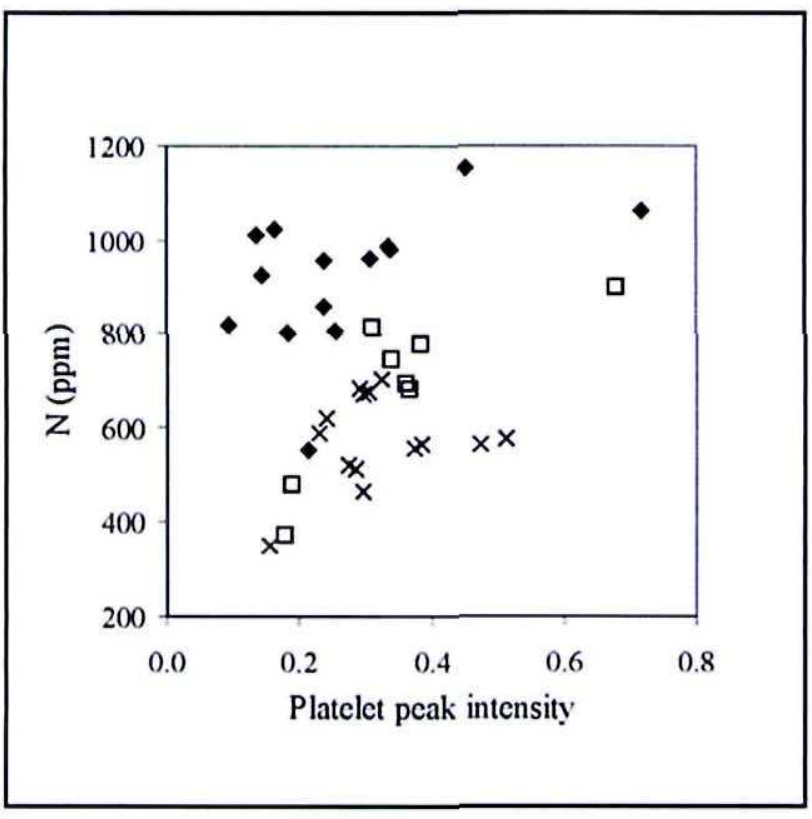

Figure 3. Nitrogen concentration versus platelet peak intensity for diamond plates. $\mathrm{P}(-9)=$ open squares, $\mathrm{A}-3=$ crosses, $17-30=$ solid diamonds.

octahedral zones, which are locally disrupted, suggestive of either brittle fracturing or partial etching/resorption while the remainder of the diamond was protected by its host rock. The rest of the plate displays alternating zones (A-F) of luminescent and non-luminescent diamond (diamond that is very dark in the CL images is from now on referred to as non-luminescent). The growth zones are in places complex but generally the luminescent diamond displays a rounded or hummocky outline typical of cuboid growth while the non-luminescent diamond often tends towards octahedral growth, best displayed in the upper left parts of the plate. Analyses B and C of plate P6-9 partially sample the non-luminescent diamond. They display low nitrogen concentrations of $373 \mathrm{ppm}$ and $482 \mathrm{ppm}$ respectively (Table 1, Figure 3 ) and low hydrogen peak intensities compared to the other analyses (Figure 4a). Analyses A, F, G and J sample predominantly the luminescent zones of the alternating luminescent/nonluminescent zones and yield enriched levels of both nitrogen $(\sim 680-780 \mathrm{ppm})$ and hydrogen (cluster of four analyses in Figure 4a) compared to analyses B and C. This suggests that the non-luminescent diamond is depleted in hydrogen as well as nitrogen compared to the luminescent diamond of the alternating luminescent/non-luminescent zones. Comparing the $\mathrm{CL}$ images of the front and rear sides of plate $\mathrm{P} 6-9$, it is evident that the brightly-luminescent octahedral zones dip steeply inwards and the "agate-texture" core does not penetrate the plate. Further, only minor nonluminescent diamond is present in the central parts of the diamond. These features imply that a single FTIR transmission point will sample more than one zone. Thus, analysis D samples partly the octahedral part of the core but perhaps mainly the adjacent poorly-
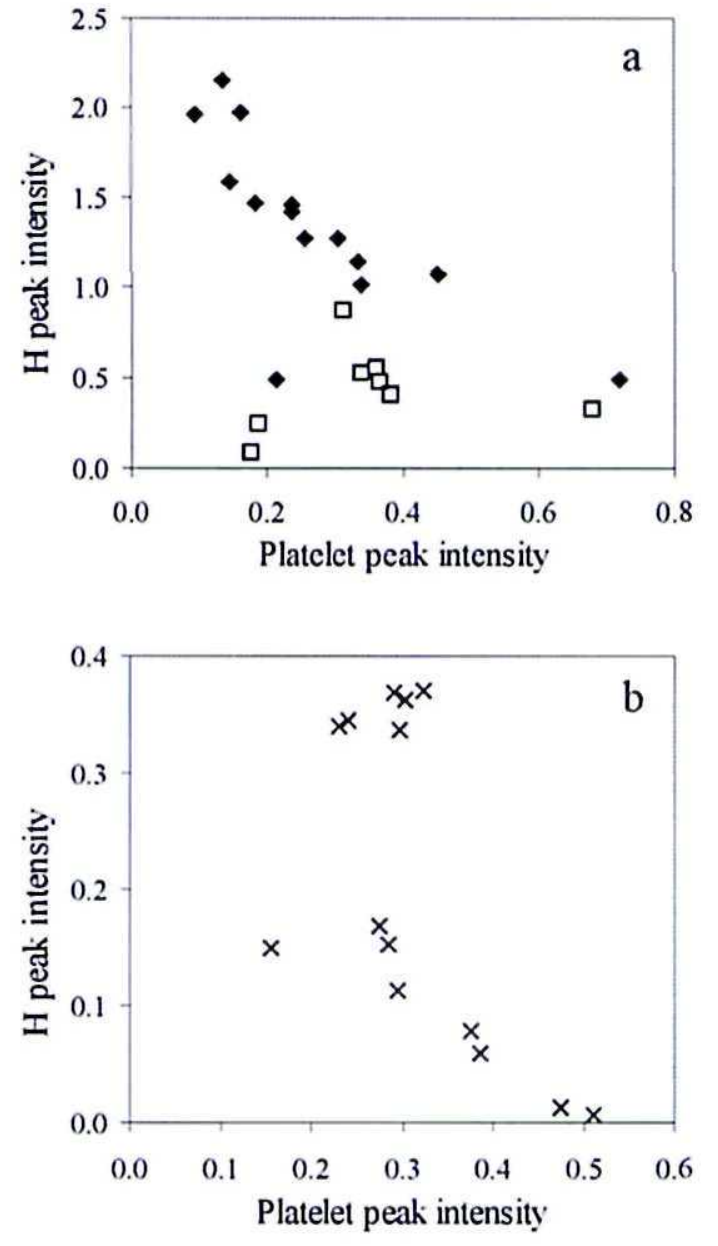

Figure 4. Hydrogen peak intensity versus platelet peak intensity for a) Plates P6-9 and 17-30 and b) Plate A-3. Symbols as in Figure 3.

luminescent (slightly darker) zone. This would explain its similar platelet peak intensity, and similar but slightly higher nitrogen and hydrogen contents compared to analyses $\mathrm{A}, \mathrm{F}, \mathrm{G}$ and $\mathrm{J}$. Analysis $\mathrm{E}$ samples the octahedral/agate texture zones of the core and it yields a similar but slightly higher nitrogen concentration $(900 \mathrm{ppm})$ than analysis D. Although the level of aggregation for analysis $\mathrm{E}$ is similar to the rest of the plate, it displays a comparatively strong platelet peak and it is also comparatively depleted in hydrogen.

Plate A-3 displays an "agate texture" core similar to Plate P6-9. The core is surrounded by luminescent diamond, which either has been resorbed or represents hummocky cuboid growth. Outwards follow irregular and partly resorbed octahedral zones of luminescent and non-luminescent diamond. The intermediate parts of the plate display alternating zones of luminescent and nonluminescent diamond similar to those of Plate P6-9) and the peripheral part of the plate consists of a broad rim of type I diamond. Analyses $\mathrm{J}$ to $\mathrm{O}$ (referred to as Group 1) from the central octahedral (and agate texture) parts yield hydrogen peak intensities between 0.3 and 
0.4 absorption units (Figure 4b) while hydrogen is below 0.2 absorption units for analyses $B$ to $G, S$ and $R$ (Group 2) from the alternating luminescent/nonluminescent diamond zones. The two groups display nitrogen contents above and below $590 \mathrm{ppm}$ respectively (Figure 3), again suggesting that nitrogen and hydrogen are coupled. Since no significant nonluminescent diamond is present on the rear side of Plate A-3, the growth zones observed on the front side extend inwards beneath the front side. Thus, both Group 1 and Group 2 analyses, except for the peripheral analyses B and $C$, have sampled multiple growth zones. Analyses $R$ and $S$ sample a significant amount of non-luminescent diamond (Figure 2) and yield the lowest nitrogen concentrations, while analyses B and C sample only the luminescent diamond rim and display the highest nitrogen concentrations in Group 2. However, the concurrent decrease in hydrogen and increase in nitrogen for Group 2 analyses is not indicative of mixed sampling of luminescent (and hydrogen-bearing) diamond and low-hydrogen non-luminescent diamond as suggested for Plate P6-9. Rather it suggests that the rim represents late-stage growth from a fluid completely depleted in hydrogen. Comparing the front and rear side CL images, the luminescent diamond of the rim is likely to have influenced many of the Group 2 analyses. Thus, the negative correlation between nitrogen and hydrogen for Group 2 analyses may be explained by partial sampling of the hydrogen deficient luminescent diamond of the rim zone. Similar to Plate P6-9, elevated platelet peak intensities for Group 2 analyses are correlated with a decrease in hydrogen intensity.

Plate 17-30 consists of a luminescent diamond core (analysis points J, I, D, C) displaying cubo-octahedral growth followed by cuboid diamond, which possibly has undergone extensive resorption. However, the apparently resorbed surface may prove to represent cuboid growth under high magnification. The core is surrounded by a thin zone of non-luminescent diamond. The intermediate parts of the plate display reasonably homogeneous luminescence and cubo-octahedral diamond, which is followed outwards by zones of strongly alternating luminescence reminiscent of Plates A-3 and P6-9. Comparing the front and rear CL images of Plate 17-30 it is evident that the alternating luminescent zones dip gently inwards (from the front to the rear side) along the sides of the diamond while the zones sampled by analysis $\mathrm{N}$ appear to dip vertically. Thus, analysis $\mathrm{N}$ has likely sampled substantial amounts of non-luminescent diamond and yields the lowest nitrogen content. Analyses A, F, G, H, L, M and N display a positive correlation between nitrogen and hydrogen (Figure 5). From the symmetrical consideration mentioned, this can be explained by sampling of different mixtures of luminescent and non-luminescent diamond. Plate $17-30$ is very rich in hydrogen (hydrogen peak intensity $\approx 0.5-2.2$ absorption units) compared to the other plates. Hydrogen peak intensities for all analyses (except analysis $\mathrm{N}$ ) are negatively correlated

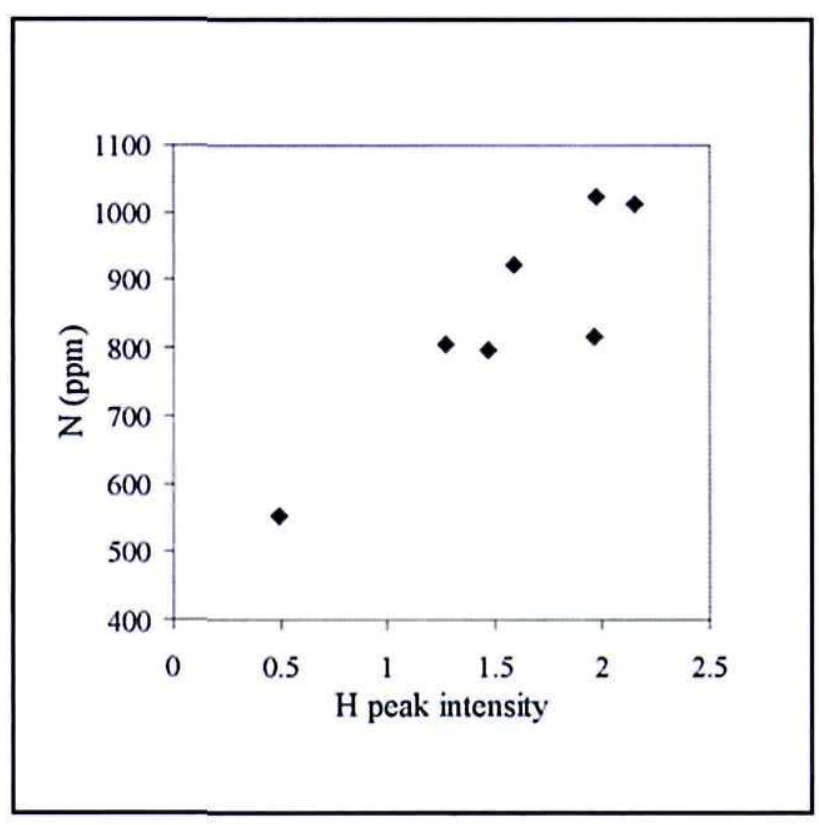

Figure 5. Nitrogen concentration versus hydrogen peak intensity for analyses A, F, G, H, L, M and N of Plate 17-30.

with platelet peak intensity (Figure 4) as observed for Group 2 of Plate A-3. This correlation is not obviously mirrored by a correlation between the nitrogen concentration and platelet peak intensity. Combining data from three plates, a strong correlation between the hydrogen peak intensity and the ratio between the amount of nitrogen present in B aggregates and platelet peak intensity is observed (Figure 6).

All three plates display considerable variations in nitrogen (P6-9: 373 to $900 \mathrm{ppm}, \mathrm{A}-3$ : 351 to $703 \mathrm{ppm}$, 17-30: 552 to $1154 \mathrm{ppm}$ ) for very restricted amounts of nitrogen aggregation (Figure 7) and it has been shown that partial analysis of non-luminescent diamond yields low nitrogen contents. The horizontal trends in Figure 7 can be explained by partial analysis of non-luminescent and nitrogen poor diamond, which would "dilute" the nitrogen concentration, whilst the estimation of nitrogen aggregation will be based on nitrogen-rich zones because of the very fact that they are rich in nitrogen (Fitzsimons et al., 1999). The nitrogen rich zones will also be ones where nitrogen aggregation proceeds most quickly (Evans, 1992). As a consequence, most analyses based on mixed nitrogen-rich and nitrogen-poor zones yield spurious over-estimations of mantle residence temperatures.

\section{Rough diamonds}

Some 129 diamonds were analysed either as rough stones or, mostly, as fragments of diamonds cracked to recover mineral inclusions. Pieces from cracked diamonds were selected to sample both the interior and the rim of the diamond. Most of the diamonds from these kimberlites (termed the low-T group) range from about 400 to $1200 \mathrm{ppm}$ in nitrogen and display low nitrogen aggregation of 10 to $40 \%$ Nitrogen as B aggregates, which yields time-averaged mantle residence 


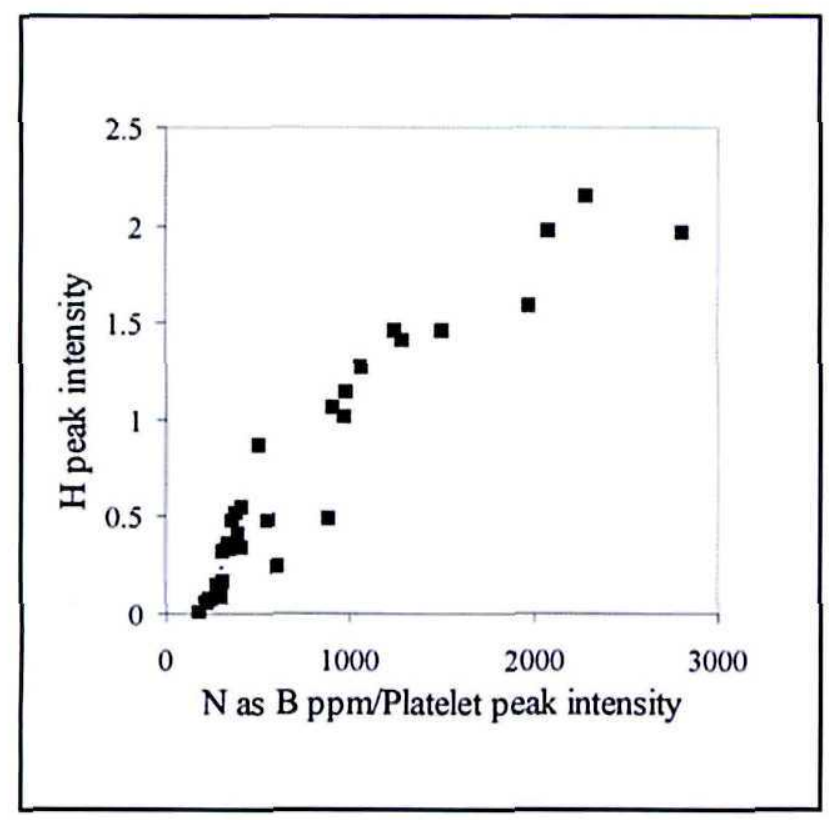

Figure 6. Hydrogen peak intensity versus the ratio between nitrogen concentration in B aggregates and platelet peak intensity for all plates.

temperatures of 1075 to $1115^{\circ} \mathrm{C}$ (Figure 8; the Main Fissure and Sugarbird Blow diamonds display similar characteristics and are, for simplicity, plotted together). The data from diamond plates cover most of the range in nitrogen concentration and aggregation state displayed by the low-T group (compare Figures 7 and 8 ; note the different scales). This suggests that much of the scatter of the low- $T$ diamonds can be attributed to partial sampling of low-nitrogen diamond (see above), which is supported by multiple analyses on some individual rough diamonds that yield a wide range in nitrogen content for a constant level of aggregation (not shown in figure). Thus, the best temperature estimation for the low-T diamonds is $\sim 1075$ to $1100^{\circ} \mathrm{C}$. A smaller number of Main Fissure and Sugarbird Blow rough or fragmental diamonds (termed the high- $\mathrm{T}$ group) display similar nitrogen concentration to the low- $\mathrm{T}$ group, but exhibit significantly higher aggregation states (Figure 8) with time-averaged temperatures of 1150 to $1180^{\circ} \mathrm{C}$. The high- $\mathrm{T}$ diamonds frequently display lamination lines indicative of plastic deformation. Six diamonds have core fragments displaying high-T type nitrogen aggregation and rim fragments with low- $T$ type aggregation. Diamonds that straddle the two groups may be due to analysis of multiple growth zones of mixed high-T/low-T diamonds. Many Marsfontein diamonds are similar in nitrogen concentration and aggregation state to the Main Fissure and Sugarbird Blow diamonds and others yield temperatures below 1060 to $1070^{\circ} \mathrm{C}$ (Figure 8). The latter suggests that the Marsfontein kimberlite has sampled a third diamond population that is not present in the Main Fissure and Sugarbird Blow kimberlites.

Figure 9 shows that the increase in platelet concentration relative to the increase in the amount of

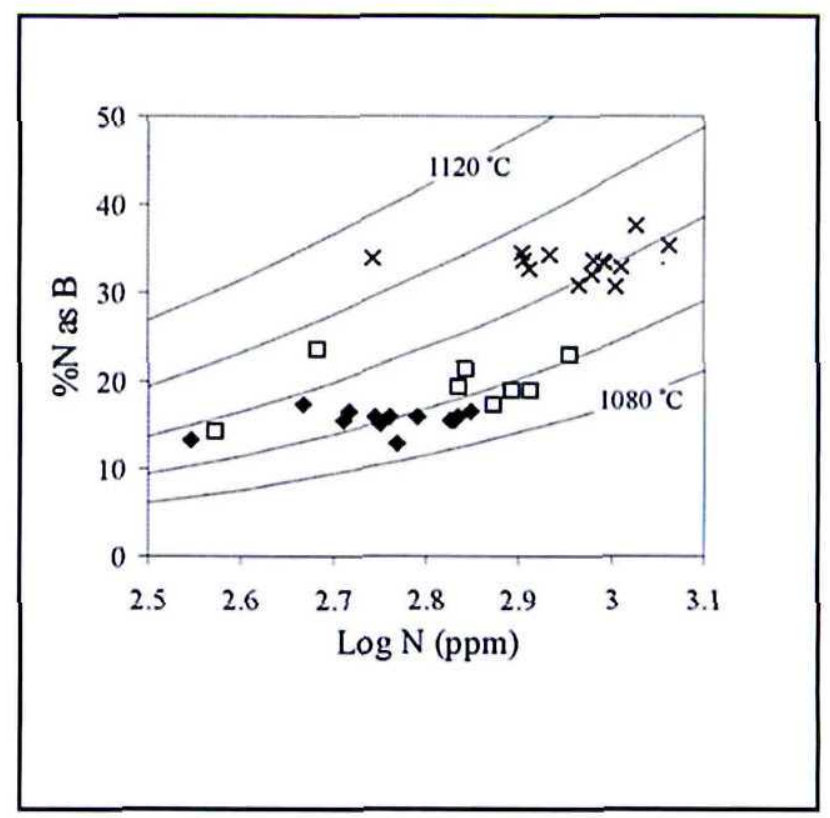

Figure 7. Nitrogen aggregation state (the percentage of the total nitrogen present as $\mathrm{B}$ aggregates) versus the nitrogen content for diamond plates. Inserted isotherms were estimated with an assumed mantle residence time of $2.5 \mathrm{Ga}$ and range from $1080^{\circ} \mathrm{C}$ to $1120^{\circ} \mathrm{C}$. Symbols as in Figure 3.

nitrogen present in B aggregates for the Klipspringer high-T group is slightly higher (lower slope) than that for the low-T group. The hydrogen intensities for the high-T group are generally below 0.1 absorption units while a high proportion of the low-T diamonds display hydrogen intensities above 0.1 .

\section{Diamond inclusion minerals}

Some 101 silicate or oxide inclusions have been recovered from a total of 40 diamonds. Thirty-five silicate-bearing diamonds have been assigned to an eclogitic paragenesis whereas 3 diamonds are classified as peridotitic and 2 as websteritic. A strong predominance of the eclogitic paragenesis is confirmed by a further 42 investigated diamonds that all contain low-Ni eclogitic sulfide inclusions (Westerlund, 2000). Only the eclogitic/grospyditic inclusions are described in this paper.

\section{Diamond inclusion compositions \\ Garnets}

Garnet inclusion compositions $(\mathrm{CaO}=3.2$ to $22.5 \mathrm{wt} . \%$, $\mathrm{FeO}=8.7$ to $21.2 \mathrm{wt} . \%, \mathrm{MgO}=5.5$ to $19.1 \mathrm{wt} . \%$ ) span most compositions displayed by eclogitic garnet inclusions worldwide and extend to compositions highly enriched in the grossular component (Figure 10). Four different populations can be distinguished by their chemical compositions (Figure 11a-d). (i) GT-I garnets form a tightly coherent group, with intermediate $\mathrm{Ca}, \mathrm{Mg}$ and $\mathrm{Fe}$ contents, and a trend towards lower $\mathrm{Ca}$ with increasing $\mathrm{Mg}$-number (Figure $11 \mathrm{a}$-d). The most Ca-rich garnets are compositionally similar to garnets in diamondbearing kyanite eclogite xenoliths (Hatton, 1978; Shee, 


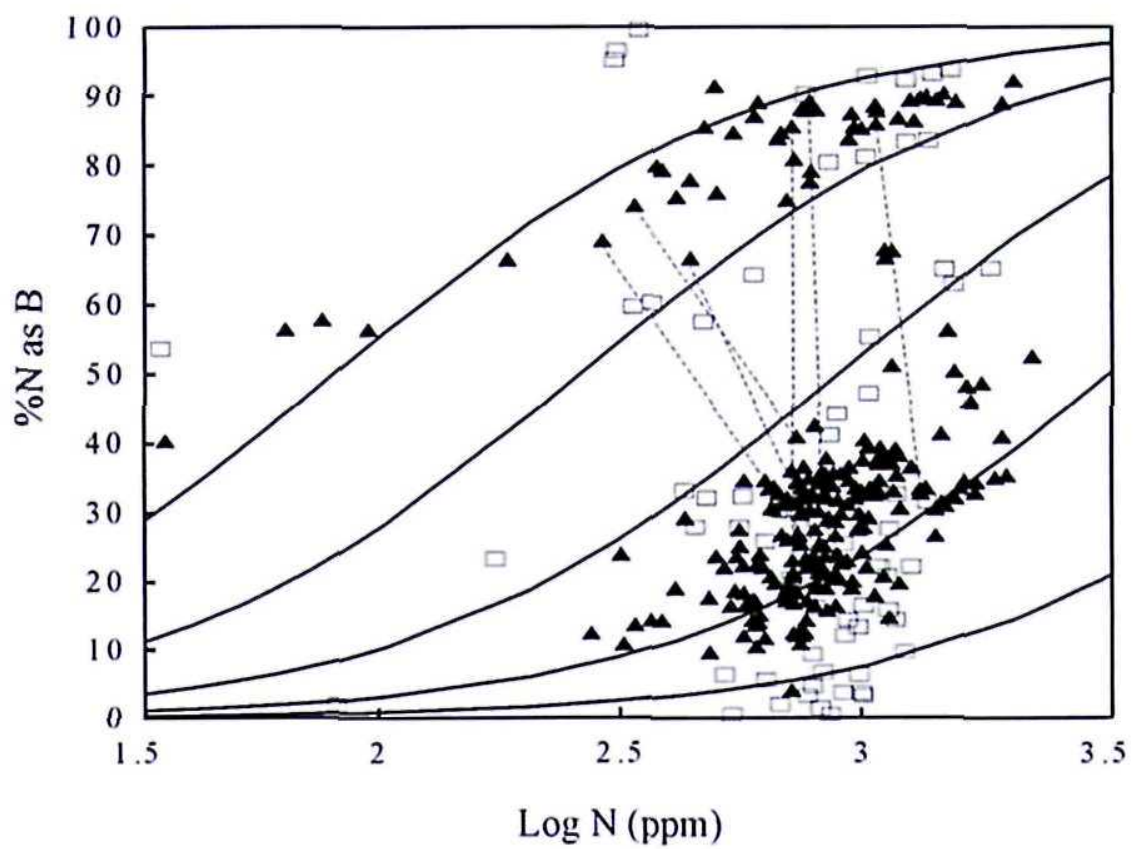

Figure 8. Nitrogen aggregation state (the percentage of the total nitrogen present as B aggregates) versus the nitrogen content for rough diamonds. Main Fissure/Sugarbird Blow=solid triangles, Marsfontein=open squares. Inserted isotherms were estimated with an assumed mantle residence time of $2.5 \mathrm{Ga}$ and range from $1060^{\circ} \mathrm{C}$ to $1180^{\circ} \mathrm{C}$. Tie lines connect individual diamonds displaying high-T cores and lowT rims.

1978). (ii) GT-II garnets trend away from GT-I garnets towards more refractory compositions $(\mathrm{Mg}=62-72)$ and are compositionally similar to garnets from bimineralic eclogite xenoliths (Hatton, 1978; Shee, 1978). Ca, Fe and $\mathrm{Mg}$ inter-element variations display a continuous

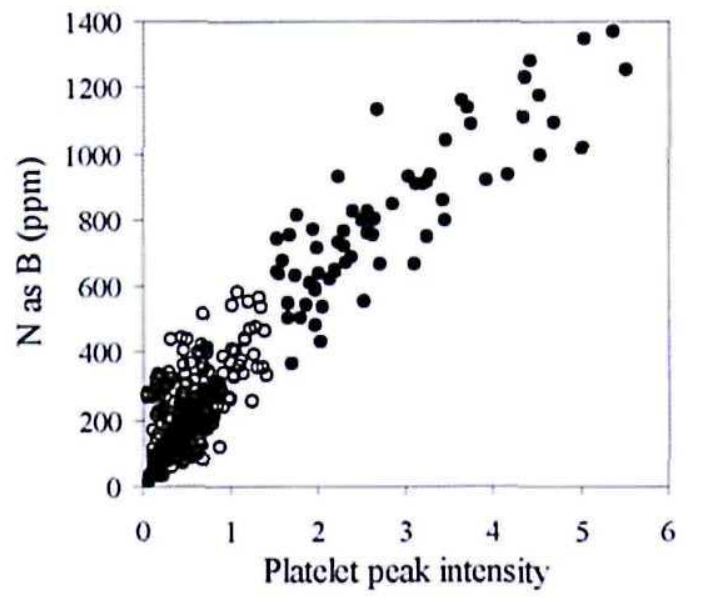

Figure 9. Nitrogen concentration in B aggregates versus platelet peak intensity for rough diamonds. Low- $T$ group=open circles, high-T group $=$ solid circles. evolution from the more refractory compositions of GTII to relatively evolved compositions of GT-I, suggesting that these groups are petrogenetically linked. (iii) GT-III garnets are distinctly depleted in $\mathrm{Fe}$ and enriched in $\mathrm{Ca}$ at any $\mathrm{Mg}$-number compared to the other groups. (iv) GT-IV garnets are enriched in Fe and depleted in $\mathrm{Mg}$ $(M g=41-44)$ compared to the other groups. As with GTI and GT-II, both the GT-III and GT-IV garnets display $\mathrm{Fe}-\mathrm{Mg}$-Ca inter-element correlations, which could be compatible with magmatic fractionation. Garnets from all groups contain high levels of $\mathrm{Na}\left(\mathrm{Na}_{2} \mathrm{O}=0.14\right.$ to 0.29 wt.\%), which is common for eclogitic garnet inclusions in diamond and garnet in diamondiferous xenoliths (McCandless and Gurney 1989).

Two diamonds (P5-2 and P8-2; both occurring in the high-T nitrogen aggregation group) contain multiple garnets, some of which fall into GT-I and others into GTII. This further suggests that the two groups are petrogenetically related. However, GT-I displays a negative correlation between $\mathrm{Fe}$ and $\mathrm{Ca}$ in contrast to GT-II, and $\mathrm{Mg}$ is depleted at a higher rate in GT-II compared to GT-I (Figures 11c and d). This suggests that the end of GT-II crystallisation and the onset of crystallisation of GT-I garnets (or their protolith) was marked by the disappearance of a Mg-rich phase such as orthopyroxene. Four inclusions from two diamonds contain very high levels of about $22 \mathrm{wt} . \% \mathrm{CaO}(\mathrm{Ca} \sim 1.8$ in Figures 11b and 11c), a grossular component of more than $60 \%$. This level of $\mathrm{CaO}$ is distinctly lower than the 


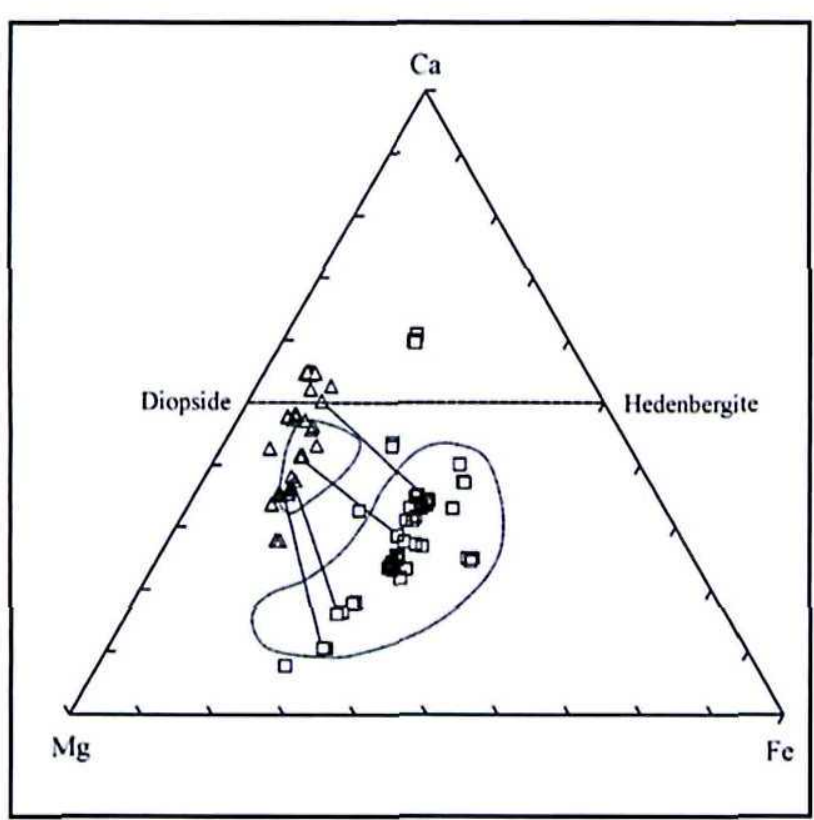

Figure 10. Fe-Mg-Ca compositions (atomic proportions) for garnet and clinopyroxene diamond inclusions. Garnet=open squares, clinopyroxene=open triangles. Tie lines connect pairs of nontouching garnet and omphacite from individual diamonds. The dotted lines define fields for worldwide compositions (from Meyer, 1985).

$\mathrm{CaO}$ content of $\sim 32 \mathrm{wt} \%$ observed in garnet inclusions of the calc-silicate suite from south-eastern Australia (Sobolev et al., 1984) but higher than for garnets from diamond-bearing kyanite eclogite xenoliths (Hatton, 1978; Shee, 1978). The composition is similar to garnets in grospydite xenoliths (Lappin, 1978; Smyth and Hatton, 1977). From major element variations it may be inferred that these high-Ca inclusions constitute an endmember of GT-III.

\section{Omphacites}

Klipspringer omphacite inclusions plot partly within and partly outside the Fe-poor side of the field for eclogitic clinopyroxene in diamond worldwide (Figure 10). The bulk of the omphacites (termed the Main group) plot below the diopside-hedenbergite join in Figure 10 and display a positive $\sim 1: 1$ correlation between $\mathrm{Al}$ and $\mathrm{Na}$ (Figure 12a) indicative of a substantial jadeite component. Unlike the garnets, the Main group omphacites do not show clear geochemical subgroups. Distinct from the Main group, there are nine omphacites plotting on or above the diopside-hedenbergite join in Figure 10, which are referred to as the high-Al group (solid symbols in Figure 12). They carry up to $16.3 \mathrm{wt} . \%$ $\mathrm{CaO}$ and they display extremely high $\mathrm{Al}$ contents $\left(\mathrm{Al}_{2} \mathrm{O}_{3}\right.$ $\sim 17$ to 19 wt.\%). The high-Al omphacites, unlike the Main group, do not have sufficient $\mathrm{Na}$ to balance $\mathrm{Al}$ and cannot support the accommodation of $\mathrm{Al}$ entirely as jadeite. Some of the Al is hosted by the Ca-tschermak end-member, which is present in amounts up to 12 mole \%. The high-Al clinopyroxenes show various amounts of site deficiency as evident from cation totals lower than four and contain 7-18\% pseudojadeite $\left(\mathrm{Ca}_{0.5} \mathrm{AlSi}_{2} \mathrm{O}_{6}\right)$ with sample $\mathrm{P} 9-2 \mathrm{e}$ showing an extremely high pseudojadeite content of $28 \%$. The high-Al group displays very low and constant levels of $\mathrm{Fe}$ while $\mathrm{Ca}$ and $\mathrm{Mg}$ decrease with increasing $\mathrm{Na}$.

The high $\mathrm{Al}$ contents together with very low Fe and $\mathrm{Mg}$ contents of the High-Al group omphacites suggest that they may be genetically linked to the GT-III garnets with grospyditic compositions. Six of the high-Al omphacites are from diamond P9-2 and they display "large-scale" disequilibrium analogous to the garnets from diamonds P5-2 and P8-2, which belong to the high$\mathrm{T}$ nitrogen aggregation group. Diamond P9-2 displays both high- $\mathrm{T}$ and low- $\mathrm{T}$ nitrogen aggregation characteristics. The omphacites carry 0.10 to $0.42 \mathrm{wt} . \%$ $\mathrm{K}_{2} \mathrm{O}$, which partly exceeds commonly observed concentrations (e.g. Gurney et al., 1979a; b; Gurney et al., 1985). There is no difference in $\mathrm{K}$ between the Main group and high- $\mathrm{Al}$ omphacites but the most Napoor/pseudojadeite-rich clinopyroxene in the High-Al group (P)-2e) is slightly depleted in $\mathrm{K}$ compared to other High-Al omphacites.

\section{Other phases}

Kyanite has only been found as two inclusions present in diamond SB-1, and since this diamond has no other inclusions, kyanite cannot be directly associated with any garnet or omphacite compositions. The kyanites may be related to the GT-I garnets which mirror the compositions of kyanite-bearing eclogites or the most Ca-rich garnets of group GT-III that were classified as grospydite garnets. One inclusion with a composition close to pure $\mathrm{SiO}_{2}$ has been recovered from diamond P9-3, and two such inclusions were found in diamond 17-7. They are believed to be coesite rather than quartz from their primary setting within the diamond. In diamond $\mathrm{P} 9-3$, the coesite occurred as a single inclusion and cannot be associated with any garnet or omphacite inclusions. However, diamond 17-7 also contained a clinopyroxene assigned to a websteritic paragenesis. Otter and Gurney (1989) reported on a coesite inclusion coexisting with a pyrope-almandine with a grossular component of $35 \%$ and Sobolev (1983) defined a coesite-eclogite diamond-inclusion paragenesis devoid of kyanite. Coesite has been reported from a grospydite xenolith with garnet containing about 19 wt.\% $\mathrm{CaO}$ (Smyth and Hatton, 1977) and is common throughout the entire compositional range of Roberts Victor group I eclogites (Schulze et al., 2000). Two rutile inclusions were found in diamonds that also contained garnets, which are amongst the less evolved group GT-I garnets. This may suggest that rutile is not associated with kyanite.

\section{Estimation of bulk rock compositions from mineral inclusion compositions}

Three diamonds (950W-2, P8-2 and SB-2) carry both pyrope-almandine and omphacite as non-touching inclusions. In diamond P8-2, multiple inclusions of both 

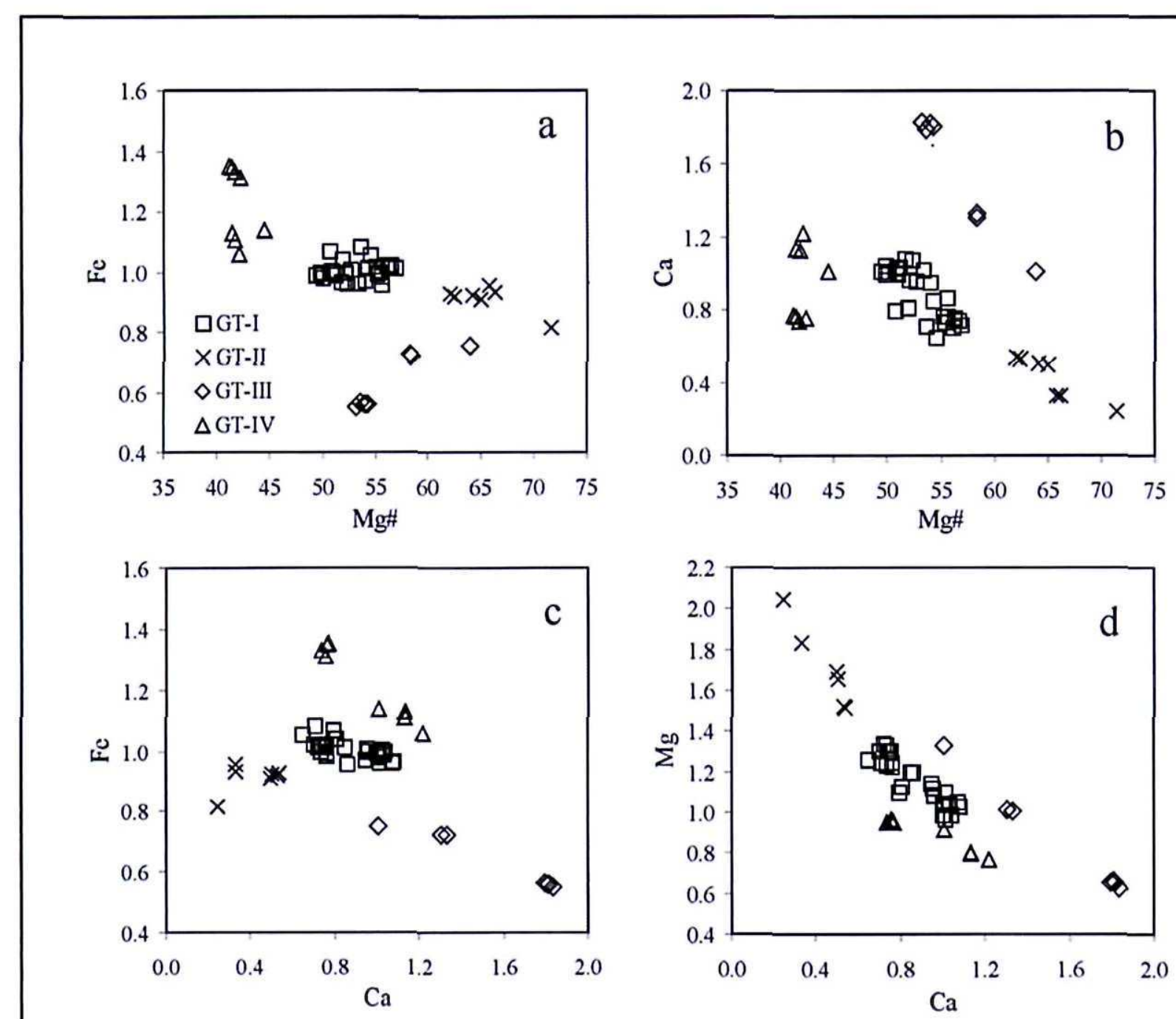

Figure 11. Inter-element relationships for diamond inclusion garnet groups GT-I, GT-II, GT-III and GT-IV (cations per 12 oxygen garnet formula unit).

pyrope-almandine and omphacite display two distinctive compositions. In Figure 10, tie lines connecting the different pairs are sub-parallel, compatible with equilibrium crystallisation. Bulk compositions of hypothetical diamond host-rocks have been estimated from these pairs, and also from GT-III garnets and High$\mathrm{Al}$ omphacites, which may be petrogenetically related as suggested above. In this second case, estimations were made for the most evolved minerals from each group. Bulk rock compositions have been estimated assuming equal modal amounts of garnet and clinopyroxene. Although this assumption may not be correct, the major element compositions of these minerals are broadly similar and a modal garnet/omphacite ratio of $60 / 40$ or $40 / 60$ instead of the assumed 50/50 would not affect the estimated bulk rock compositions significantly. The minerals from diamond $950 \mathrm{~W}-2$ are similar in composition to their counterparts in kyanite eclogites, and the most evolved GT-III garnet (P3-1) and High-Al omphacite (P7-3) are similar in composition to these minerals in grospydites. Kyanite eclogites and grospydites commonly carry between 5 and 20 modal per cent kyanite (e.g. Ater et al., 1979; Shee, 1978; Smyth and Hatton, 1977; Lappin, 1978). Therefore, bulk rock estimations based on inclusions from 950W-2 and P31/P7-3 were also performed assuming 10 and 20 modal $\%$ kyanite. Similar to the $\mathrm{Al}$ dependence on kyanite, $\mathrm{Ti}$ and $\mathrm{Si}$ contents are dependent on the assumed amount of rutile and coesite respectively. Potassium and $\mathrm{Na}$ are sensitive to the assumed modal abundance of clinopyroxene since $\mathrm{K}$ exclusively and Na mainly occurs in clinopyroxene (assuming a phlogopite-free environment). In addition, large-ion lithophile elements like $\mathrm{K}$ and high field strength elements like $\mathrm{Ti}$ are very sensitive to partial melting and/or metasomatism of the protolith. Therefore we place emphasis on $\mathrm{Fe}, \mathrm{Ca}$, $\mathrm{Mg}$ and $\mathrm{Al}$ (which has been accounted for through the addition of kyanite) as the elements, which best can reflect the compositions of hypothetical protoliths.

The estimated eclogite compositions are presented in Table 2. Representative compositions for mid-ocean 

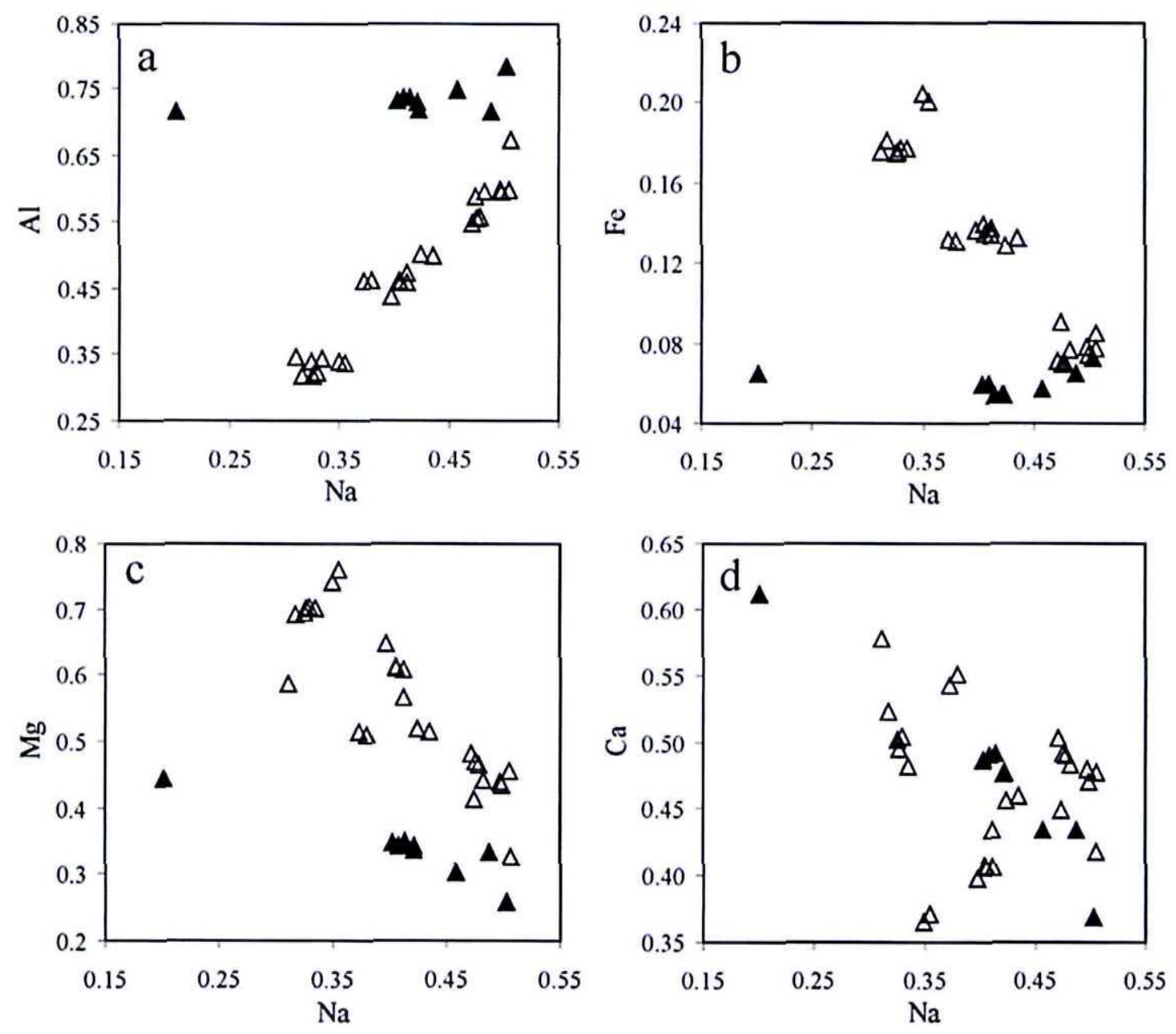

Figure 12. Inter-element relationships for diamond inclusion clinopyroxene showing the Main group (open triangles) and the High-Al group (filled triangles) (cations per 6 oxygen pyroxene formula unit).

ridge basalts (MORB), mid-ocean ridge (MOR) cumulates and komatites, which have been suggested as protoliths for mantle eclogites, are given in Table 3. SB-2 displays the most refractory composition and is compositionally similar to the most refractory MOR cumulates. Its $\mathrm{MgO}$ (15 wt.\%) content is higher than commonly observed for MORB. Komatiites may range down to $\sim 15 \mathrm{wt} . \% \mathrm{MgO}$ (and down to $\sim 10 \mathrm{wt} . \% \mathrm{MgO}$ for basaltic komatiites) but the $\mathrm{Al}_{2} \mathrm{O}_{3}$ content of SB-2 is distinctly higher than that generally displayed by komatiites.

All compositions displayed by $950 \mathrm{~W}-2$ are too fertile to be akin to komatiite. Further, even the most refractory composition (950W-2(0); kyanite-free estimation) displays distinctly higher $\mathrm{Al}_{2} \mathrm{O}_{3}$ than is commonly displayed by MORB. All estimated compositions are however covered by the compositional range displayed by the MOR cumulates. $950 \mathrm{~W}-2(0)$ is similar in composition to kyanite-bearing eclogite (Hatton, 1978; Shee, 1978) but if 10 to 20 modal \% kyanite is added, the $\mathrm{Al}_{2} \mathrm{O}_{3}$ distinctively exceeds the range observed for kyanite eclogite and enters that of grospydite (Smyth and Hatton, 1977; Lappin, 1978). Since garnet from 950W-2 is akin to kyanite-bearing eclogite garnet rather than grospydite garnet, this suggests that only minor kyanite was associated with the $950 \mathrm{~W}-2$ paragenesis. Thus, the composition of a hypothetical protolith for this paragenesis is probably closer to that of $950 \mathrm{~W}-2(0)$ than those of $950 \mathrm{~W}-2(10)$ and $950 \mathrm{~W}-2(20)$.

Chemical compositions for P8-2(I) and P8-2(II) are similar to each other and intermediate between those of SB-2 and 950W-2(0). P8-2(I) and P8-2(II) are much too elevated in $\mathrm{Al}_{2} \mathrm{O}_{3}$ to resemble even basaltic komatiites while they are fairly similar to MORB in composition. However, their $\mathrm{MgO}$ and $\mathrm{Al}_{2} \mathrm{O}_{3}$ contents are slightly higher than commonly observed for MORB and they are compositionally akin to some MOR cumulates.

In a similar way to $950 \mathrm{~W}-2$, the estimated bulk rock chemistry based on P3-1 (garnet) and P7-3 (omphacite) is dependent on the assumed modal content of kyanite. These compositions are all distinctly higher in $\mathrm{CaO}$ and $\mathrm{Al}_{2} \mathrm{O}_{3}$ and lower in $\mathrm{FeO}$ and $\mathrm{MgO}$ compared to MORB 
Table 2. Bulk-rock compositions estimated from garnet and omphacite inclusions.

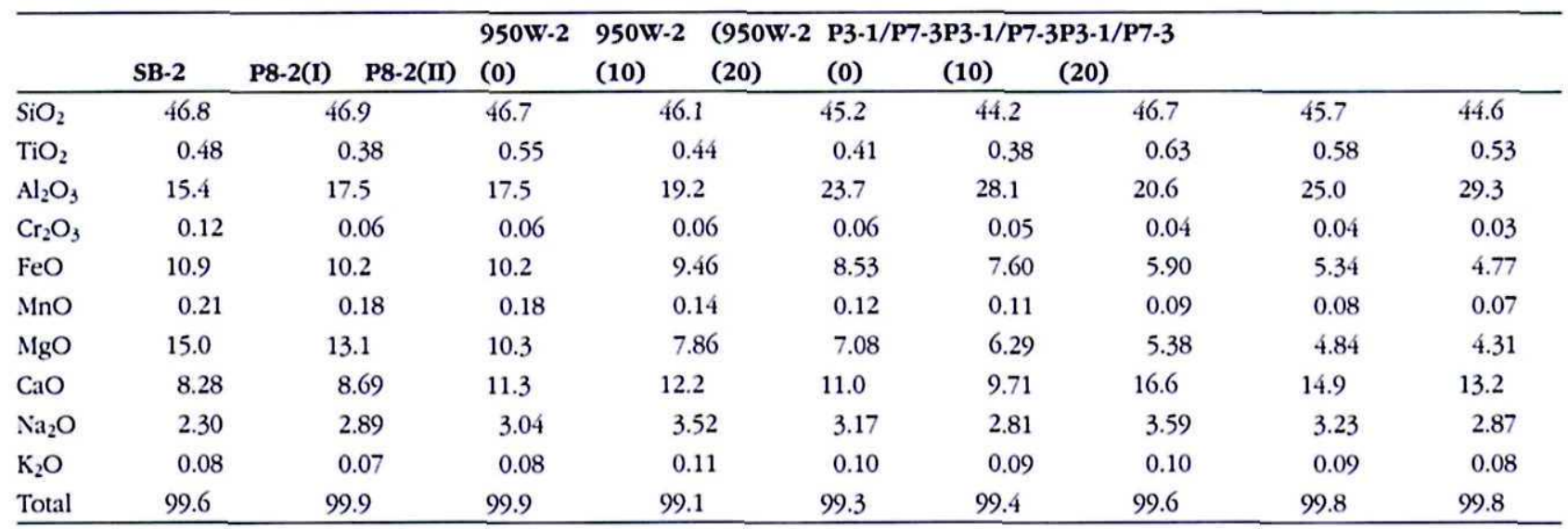

Equal modal proportions of garnet and omphacite were assumed. Indices $(0),(10)$ and $(20)$ indicate modal\% kyanite.

and komatiite. The whole estimated compositional range however falls within that of MOR cumulates. Analysis P3-1/P7-1(20) with 20 modal \% kyanite is very similar in composition to a grospydite from Roberts Victor, which contains 20 modal \% kyanite (Lappin, 1978).

\section{Diamond incluston geothermometry}

While no reactions involving garnet and clinopyroxene result in sufficient volume change to yield information on the pressure of equilibration, the four non-touching garnet-omphacite pairs in diamonds $950 \mathrm{~W}-2, \mathrm{P} 8-2$ and SB-2 may be used to estimate the temperature of diamond formation. The basis for garnet-clinopyroxene geothermometry is the temperature dependence of $\mathrm{Fe}^{2+}$ and $\mathrm{Mg}$ partitioning between the two minerals. Chemical equilibrium cannot simply be assumed since the inclusions may have been incorporated into the diamond at different times, in different chemical environments and/or under different temperature conditions. However, in Figure 10, tie-lines connecting the garnets and omphacites are not crossing which suggests, or at least does not preclude, that the different mineral pairs crystallised under potentially similar equilibrium conditions. Four experimentally calibrated and commonly used geothermometers were evaluated in detail by Westerlund (2000): Ellis and Green (1979), Krogh (1988), Ai (1994) and Berman et al. (1995). Based on the results from the application of these geothermometers on Klipspringer eclogitic diamond inclusions and xenoliths, it was proposed that Krogh (1988) yields the most realistic temperatures for the current range in composition. The obtained temperature ranges are 1152 to $1233^{\circ} \mathrm{C}$ at an assumed pressure of 50 kbars and 1200 to $1278^{\circ} \mathrm{C}$ at an assumed pressure of 60 kbars (Table 4).

\section{Discussion and conclusions}

Woods (1986) suggested that platelets are formed from carbon atoms expelled from the diamond lattice during the formation of $\mathrm{B}$ aggregates. However, platelet peak development may occur at different rates relative to the amount of B aggregates (Mendelssohn and Milledge,

Table 3. Selected compositions of $\mathrm{MORB}, \mathrm{MOR}$ cumulates and komatiites. Total $\mathrm{Fe}$ is given as either $\mathrm{FeO}$ or $\mathrm{Fe}_{2} \mathrm{O}_{3}$.

\begin{tabular}{|c|c|c|c|c|c|c|c|c|c|c|c|c|c|c|c|}
\hline & $\begin{array}{c}\text { MORB } \\
1\end{array}$ & $\begin{array}{c}\text { MORB } \\
2\end{array}$ & $\begin{array}{c}\text { CUM } \\
3\end{array}$ & $\begin{array}{c}\text { CUM } \\
3\end{array}$ & $\begin{array}{c}\text { CUM } \\
3\end{array}$ & $\begin{array}{c}\text { CUM } \\
3\end{array}$ & $\begin{array}{c}\text { CUM } \\
3\end{array}$ & $\begin{array}{c}\text { CUM } \\
3\end{array}$ & $\begin{array}{c}\text { CUM } \\
3\end{array}$ & $\begin{array}{c}\text { KOM } \\
4\end{array}$ & $\begin{array}{c}\text { KOM } \\
5\end{array}$ & $\begin{array}{c}\text { KOM } \\
5\end{array}$ & $\begin{array}{c}\text { KOM } \\
6\end{array}$ & $\begin{array}{c}\text { KOM } \\
6\end{array}$ & $\begin{array}{c}\text { KOM } \\
6\end{array}$ \\
\hline$\overline{\mathrm{SiO}_{2}}$ & 49.7 & 49.4 & 48.9 & 50.5 & 48.1 & 47.2 & 45.3 & 50.0 & 50.0 & 49.1 & 47.3 & 41.5 & 50.1 & 48.5 & 52.6 \\
\hline $\mathrm{TiO}_{2}$ & 1.55 & 1.37 & 0.34 & 0.31 & 0.17 & 0.12 & 0.10 & 0.34 & 0.06 & 0.41 & 0.35 & 0.48 & 1.21 & 1.30 & 0.65 \\
\hline $\mathrm{Al}_{2} \mathrm{O}_{3}$ & 15.2 & 15.9 & 15.6 & 20.5 & 25.0 & 19.7 & 22.0 & 17.5 & 29.1 & 4.65 & 7.95 & 9.60 & 9.91 & 10.0 & 6.96 \\
\hline $\mathrm{Cr}_{2} \mathrm{O}_{3}$ & & & & & & & & & & 0.37 & & & & & \\
\hline $\mathrm{FeO}$ & 10.3 & 9.54 & & & & & & & & 11.4 & 11.9 & 13.5 & 13.5 & 14.5 & 11.1 \\
\hline $\mathrm{Fe}_{2} \mathrm{O}_{3}$ & & & 8.17 & 4.65 & 3.29 & 4.59 & 5.09 & 3.87 & 1.44 & & & & & & \\
\hline $\mathrm{MnO}$ & 0.18 & 0.17 & 0.13 & 0.08 & 0.05 & 0.08 & 0.07 & 0.08 & 0.02 & 0.20 & 0.20 & 0.25 & 0.18 & 0.23 & 0.17 \\
\hline $\mathrm{MgO}$ & 8.01 & 7.14 & 14.8 & 8.34 & 7.02 & 14.0 & 14.3 & 9.45 & 3.00 & 23.2 & 24.9 & 21.9 & 11.0 & 10.8 & 13.1 \\
\hline $\mathrm{CaO}$ & 11.2 & 11.1 & 11.4 & 13.0 & 14.2 & 12.8 & 11.3 & 16.0 & 13.1 & 10.2 & 7.18 & 6.30 & 11.8 & 12.1 & 10.8 \\
\hline $\mathrm{Na}_{2} \mathrm{O}$ & 2.59 & 2.74 & 1.78 & 2.67 & 2.07 & 1.21 & 1.02 & 1.86 & 3.21 & 0.03 & 0.01 & 0.04 & 0.26 & 0.22 & 0.11 \\
\hline $\mathrm{K}_{2} \mathrm{O}$ & 0.30 & 0.33 & 0.02 & 0.02 & 0.01 & 0.04 & 0.28 & 0.01 & 0.02 & 0.28 & 0.22 & 0.32 & 1.24 & 1.54 & 1.61 \\
\hline Total & 100.4 & 100.2 & 101.2 & 100.0 & 100.0 & 99.7 & 99.4 & 99.1 & 99.9 & 99.8 & 100.0 & 93.9 & 99.1 & 99.2 & 97.1 \\
\hline
\end{tabular}

${ }^{1}$ MORB - mid-Atlantic ridge (le Roex et al., 1987); ${ }^{2} \mathrm{MORB}$ - Southwest Indian ridge (le Roex ef al., 1989); ${ }^{3} \mathrm{MOR}$ cumulates - Southwest Indian ridge (Meyer et al., 1989); ${ }^{4}$ Komatiite - Barberton greenstone belt, South Africa (Parman et al., 1997); ${ }^{5}$ Komatiites - Wawa greenstone belts, Canada (Polat et al., 1999); 'Basaltic komatiites - the Onverwacht group, South Africa (Jahn et al., 1982). 
1995). While platelet degradation may be explained by catastrophic heating events (Woods, 1986), Mendelssohn and Milledge (1995) suggest that a lower rate of platelet development may be expected during nitrogen aggregation at higher temperatures from the higher reluctance for carbon atoms to relax back into the diamond lattice at higher temperatures. The correlation between the hydrogen peak intensity and the ratio between the amount of nitrogen occurring in $B$ aggregates and the platelet peak for the diamond plates as well as the comparatively lower hydrogen content of the high-T diamonds, which display a higher increase in platelet peak intensity relative to $B$ aggregates than the low- $T$ diamonds, suggest that hydrogen also may affect the formation or degradation of platelets.

Silicate inclusion compositions indicate that eclogitic parageneses strongly dominate amongst Klipspringer diamonds. Based on garnet and clinopyroxene inclusion compositions, the presence of both rutile and garnet in two individual diamonds, and the occurrence of kyanite inclusions, three parageneses have been recognised: eclogite \pm rutile \pm kyanite paragenesis (GT-I/GT-II), a grospydite paragenesis (GT-III/High-Al omphacites) and an Fe-rich eclogitic paragenesis (GT-IV). The major element variations suggest that the garnets within each individual group may be linked by magmatic fractionation. However, the grospydite and Fe-rich parageneses cannot be related to the first eclogite paragenesis by a simple petrogenetic process.

A level of 28 mole $\%$ pseudojadeite has not previously been reported for either clinopyroxene inclusions or xenolithic clinopyroxene. Since the inclusions are protected by the diamond host from reequilibration with the surrounding environment, the observed pseudojadeite contents of the high-Al omphacites may be indicative of intrinsic compositions that cannot be observed in xenolithic omphacite due to decompression breakdown (Smyth, 1980; Smyth et al., 1989). Experiments in the system $\mathrm{Na}_{2} \mathrm{O}-\mathrm{CaO}-\mathrm{Al}_{2} \mathrm{O}_{3}-\mathrm{SiO}_{2}$ show that the pseudojadeite content of clinopyroxene is strongly pressure dependent and increases with increasing pressure up to $\sim 35$ kbars (Gasparik, 1985). The comparatively small cell volume of nonstoichiometric clinopyroxene would also favour increased stability at higher pressures (Wood and Henderson, 1978). The solubility of $\mathrm{K}$ in clinopyroxene increases with increasing pressure under upper mantle conditions (Harlow, 1992). Thus, assuming that $\mathrm{K}$ is buffered, the concurrent low level of $\mathrm{K}$ and high level of pseudojadeite in P9-2e compared to the rest of the High$\mathrm{Al}$ omphacites suggests that the elevated pseudojadeite content is not reflecting a higher pressure. Rather the amount of pseudojadeite is determined by the bulk composition of the environment of formation. Since the $\mathrm{Al}_{2} \mathrm{O}_{3}$ content of garnet is fairly constant at different eclogitic whole-rock compositions, the variations in bulk $\mathrm{Al}_{2} \mathrm{O}_{3}$ of the environment are reflected in the $\mathrm{Al}_{2} \mathrm{O}_{3}$ content of clinopyroxene and the possible presence of
Table 4. Temperatures estimated from non-touching garnetclinopyroxene pairs from individual diamonds using the Krogh (1988) geothermometer.

\begin{tabular}{lcccc}
\hline Sample & lnK $_{\mathbf{d}}$ & $\mathbf{X}_{\mathbf{C a}}$ & $\begin{array}{c}\mathbf{T}\left({ }^{\circ} \mathrm{C}\right) \\
\text { P-50 kbar }\end{array}$ & P-60 kbar \\
\hline SB-2 & 0.71 & 0.11 & 1152 & 1200 \\
P8-2(I) & 1.15 & 0.28 & 1188 & 1226 \\
P8-2(II) & 0.81 & 0.16 & 1233 & 1278 \\
950W-2 & 1.27 & 0.35 & 1203 & 1241 \\
\hline
\end{tabular}

kyanite and/or corundum. The very high $\mathrm{Al}_{2} \mathrm{O}_{3}$-levels of the reconstructed grospydite bulk composition and particularly the constant level of $\mathrm{Al}$ in the High-Al omphacites with increasing and decreasing contents of other elements, indicate that the environment was buffered with respect to $\mathrm{Al}_{2} \mathrm{O}_{3}$. This suggests that kyanite was present, as one would expect for a grospydite paragenesis. Both the GT-III garnets and the high-Al omphacites display distinctive inter-element variations that can be reconciled with magmatic fractionation. Although kyanite is expected to be present in the grospydite paragenesis, it is suggested that excessive amounts of $\mathrm{Al}$ in the formation environment were initially accommodated partly in pseudojadeite. While $\mathrm{Ca}$ increases with decreasing $\mathrm{Mg}$ for the GT-III garnets, $\mathrm{Ca}$ (and the pseudojadeite content) decreases and $\mathrm{Na}$ increases with decreasing $\mathrm{Mg}$ for the high-Al omphacites. Clinopyroxene is the only phase beside melt in a deep lithospheric environment that can host $\mathrm{Na}$ to a significant extent. Thus, as $\mathrm{Na}$ becomes concentrated in a magma due to fractionation of garnet and Na-deficient clinopyroxene, at some point it starts to enter the clinopyroxene. Garnet and clinopyroxene are the only phases to accommodate $\mathrm{Ca}$. Therefore $\mathrm{Ca}$ will increase in the garnet as $\mathrm{Na}$ enters the clinopyroxene. Thus, the observed range in pseudojadeite content (2-28 mole \%) of the clinopyroxene is proposed to be dependent on the composition of the protolith and perhaps magmatic fractionation of a partial melt of the protolith rather than the prevalent pressures of formation of the clinopyroxene. Bulanova et al. (1988, in Russian, cited by Bulanova, 1995) interpreted a decrease in the pseudojadeite content of clinopyroxene diamond inclusions as a decrease in pressure of formation based on a qualitative estimation of the pressure sensitivity of pseudojadeite (Jarikov et al., 1984, in Russian, cited by Bulanova, 1995). We suggest that any information on the pressure of equilibration based on the level of pseudojadeite in clinopyroxene may be in error if the bulk composition and whole mineral assemblage are not known.

The low- $T$ and high- $T$ nitrogen aggregation group diamonds are well separated in Figure 8 indicating that they are two petrogenetically unrelated populations representing two discrete diamond formation events. However, the presence of six individual diamonds, which are mixtures of low- $\mathrm{T}$ and high-T diamonds, 
suggests that the two populations were spatially related in the upper mantle. The central location of the high-T analyses and the peripheral location of the low- $T$ analyses implies that the former predate the latter and it suggests that in some cases the high-T diamonds have acted as nucleation sites for the low-T diamonds. $A$ time gap of 50 to 200 million years between the high-T and low- $T$ diamond formation with temperatures in the range of 1220 to $1260^{\circ} \mathrm{C}$ would allow for the former to achieve their comparatively enhanced nitrogen aggregation state. A time gap of less than 10 million years would demand unreasonably high temperatures. However, many high-T diamonds show evidence of high-temperature deformation in the form of lamination lines (Westerlund, 2000). Plastic deformation may enhance nitrogen aggregation (Evans, 1992) in which case the estimated time-averaged mantle residence temperatures for the high-T diamonds would be spurious. Westerlund et al. (this volume) propose that the low- $\mathrm{T}$ diamonds are related to the $\sim 2.7 \mathrm{Ga}$ Ventersdorp event. It may be speculated that plastic deformation of the high-T diamonds occurred just prior to the formation of the low-T diamonds and was associated with a tectonothermal event responsible for the reactivation of the Thabazimbi-Murchison Lineament at $2.7 \mathrm{Ga}$. The "large-scale" disequilibrium displayed by inclusions from three high- $T$ nitrogen aggregation group diamonds is difficult to reconcile with a metamorphic origin through solid state diffusion or simple recrystallisation of pre-existing garnet and clinopyroxene since this would require a substantial chemical disequilibrium on a micrometre scale in the eclogitic host-rock. The "large-scale" disequilibrium trends are concordant with the magmatic fractionation trends displayed by the respective parageneses which suggests an igneous or metasomatic origin for the high$\mathrm{T}$ diamonds.

Based on a detailed study of the low-T diamond internal growth characteristics and the Re-Os and $\mathrm{S}$ isotope systematics of their sulfide inclusions, Westerlund et al. (2004) argue for an origin of the diamonds by the remobilization of fluids in or proximal to a pre-existing eclogite host rock. Some diamonds from each of the three garnet inclusion parageneses occur in the high-T nitrogen aggregation group while other diamonds from each paragenesis occur in the low-T nitrogen aggregation group. The inclusions from the high-T and the low- $T$ diamonds conform to the same compositional trends which suggest that the low-T diamonds formed in the host-rock for the high-T diamonds and their silicate inclusions acquired their compositions from the surrounding host eclogite/ grospydite. The inclusions in the low-T group diamonds may have precipitated from a partial melt of the host eclogite/grospydite. However, in such a scenario one would expect the silicate inclusions from the low- $T$ diamonds to consistently display more evolved compositions than the silicate inclusions from the high-T diamonds, which is not the case. We propose that the silicate inclusions in the low- $T$ diamonds originate from recrystallisation of pre-existing minerals in connection with the late-Archean metasomatic event.

Several lines of evidence point at subducted oceanic crust as a protolith for upper mantle eclogites and eclogitic diamonds (see Introduction). Hypothetical reconstructed eclogitic/grospyditic protoliths for the silicate inclusions display a wide range in $\mathrm{FeO}, \mathrm{MgO}$, $\mathrm{CaO}$ and $\mathrm{Al}_{2} \mathrm{O}_{3}$. Despite the wide compositional range, none of the estimated bulk rock compositions is akin to those of MORB or komatiite. However, the estimated abundances of most elements are covered by the range displayed by MOR cumulates from the Southwest Indian Ridge. This may suggest that while the different observed garnet inclusion groups are not directly petrogenetically related, their protoliths may be different types of mid-ocean ridge layer 3 cumulates. However, all estimated compositions display low levels of $\mathrm{SiO}_{2}$ compared to MOR cumulates. If MOR cumulates are indeed protoliths for the inclusions, it may be that coesite was present in the different parageneses which has not been accounted for in the bulk rock chemistry estimations. Alternatively, any silica present as a $\mathrm{SiO}_{2}$ phase may have been lost during subduction and partial melting of the oceanic crust as suggested by Rudnick (1995). The reconstructed bulk composition for the grospydite paragenesis, based on the high-Ca garnets and high-Al omphacites, would have been derived from a close to pure anorthosite cumulate as has previously been suggested for mantle grospydites (Jagoutz et al., 1984).

The time-averaged mantle residence temperatures for the low-T diamonds $\left(\sim 1075\right.$ to $\left.1100^{\circ} \mathrm{C}\right)$ are similar to the equilibration temperatures for the Group I eclogites (see Geological setting and the Klipspringer kimberlites), which are believed to have recorded the temperatures that prevailed in the lithosphere within the diamond stability field at the time of kimberlite eruption $148 \mathrm{Ma}$ ago. This suggests that the diamondiferous part of the lithosphere at the time of low- $\mathrm{T}$ diamond formation $(2.55 \pm 0.15 \mathrm{Ga})$ cannot have been much hotter than at $150 \mathrm{Ma}$ ago. Thus, a cratonic geotherm of 37 to 39 $\mathrm{mW} / \mathrm{m}^{2}$ was already established around the Proterozoic/Archaean boundary. The equilibration temperatures for non-touching garnet and omphacite inclusions are some 80 to $150^{\circ} \mathrm{C}$ higher than those of the Group I eclogites and the time-averaged mantle residence temperatures for the low-T group diamonds. While it cannot be excluded that the recorded temperature difference reflects a mechanical transport of the diamonds to a shallower lithospheric level subsequent to diamond formation, a metasomatic process of formation was more probably associated with a heating event and a temporarily increased geotherm. The implications are that the low- $T$ diamonds were formed during a thermal perturbation of the lithosphere and were stored under thermal conditions similar to those prevalent in the mantle 150 Ma ago. 


\section{Acknowledgements}

This study is a contribution to the multi-national, multidisciplinary Anatomy of an Archaean Craton project which brought together researchers from N. America and Southern Africa in a geophysical, structural, petrological, geochemical and geochronological study of the Kaapvaal and Zimbabwe cratons and their neighbouring terrains. Financial support for this study was received from Southern Era, BHP Minerals, Mineral Services, University of Cape Town and the National Research Foundation (Pretoria) and is gratefully acknowledged. Particular thanks are due to Dr Chris Jennings and David Gadd-Claxton for active cooperation in facilitating access to the inclusion bearing diamonds shortly after discovery of the Klipspringer kimberlites. Constructive reviews by Ben Harte and Ingrid Chinn substantially improved the manuscript.

\section{References}

Ai, Y. (1994). A revision of the garnet-clinopyroxene $\mathrm{Fe}^{2 *}-\mathrm{Mg}$ exchange geothermometer. Contributions to Mineralogy and Petrology: 115. $467-473$.

Ater, P.C., Eggler, D.H. and McCallum, M.E. (1979). Petrology and geochemistry of mantle eclogite xenoliths from Colorado-Wyoming kimberlites: Recycled oceanic crust? In: J. Kornprobst (Editor), Kimlerlites 11: The Mantle and Crust-Mantle Relationships, Elserier, Amsterdam, The Netberlands, 309-318.

Berman, R.G., Aranovich, L.Ya. and Pattison, D.R.M. (1995). Re:assessment of the garnet-clinopyroxene Fe-Mg exchange thermometer: II. Thermodynamic analysis. Contributions to Mineralogy and Petrology: 119. $30-42$.

Boyd, F.R. and Gurney, J. (1986). Diamonds and the African lithosphere. Science, 232, 472-477.

Bulanova, G.P. (1995). The formation of diamond. Jotrnal of Geocbemical Exploration. 53. 1-23.

Bulanova, G.P. and Griffin. B.J. (1995). The origin of complex "agate" textures in octahedral diamonds from kimberlites. Gtb International Kimberlite Conference, Notosibirsk, Russia, (extended abstracts), 74-76.

Bulanova, G.P., Novgorodov, P.G. and Pavlova, L.A. (1988). A first find of melt inclusion in diamond from Mir pipe. Geokbimiya, 5, 756-765. (in Russian).

Cartigny, P., Harris, J.W. and Javoy, M. (1998a). Eclogitic diamond formation at Jwaneng: No room for a recycled component. Science, 280, 1421-1424.

Cartigny, P., Harris, J.W., Phillips, D., Boyd, F.R. and Javoy, M. (1998b). Subducted-related diamonds? The evidence for a mantle derived origin from coupled d $\mathrm{d}^{15} \mathrm{C}-\mathrm{d}^{15} \mathrm{~N}$ determinations. Cbemical Geology; 147, 147-159.

Clark, C.D., Collins, A.T., and Woods, G.S. (1992). Absorption and luminescence spectroscopy. In: J.E. Field (Editor), The properties of natural and synthetic diamond, Academic Press, London, U.K., 35-79.

Deines, P. and Harris, J.W. (1995). Sulfide inclusions chemistry and carton isotopes of African diamonds. Geochimica et Casmocbimica Acta. 59. 3173-3188.

Fldridge, C.S., Compston, W., Williams, I.S., Harris, J.W. and Bristow, J.W, (1991). Isotope evidence for the involvment of recycled oceanic sediments in diamond formation. Nature, 353, 649-653.

Ellis, D.J. and Green, D.H. (1979). An experimental study of the effect of Ca upon garnet-clinopyroxene Fe-Mg exchange equilibria. Contributions to .Mineralogy and Petrology: 71, 13-22.

Evans, T, (1992). Aggregation of nitrogen in diamond. In: J.E. Field (Editor), The properties of natural and synthetic diamond, Academic Press, London. U.K., 259-290.

Evans, T. and Qi, Z. (1982). The kinetics of the aggregation of nitrogen atoms in diamond. Proceedings of tbe Royal Socicty of London, A381, 159-178.

Fitzsimons, I.C.W., Harte, B., Chinn, I.L., Gurney. J.J. and Taylor, W.R. (1999). Extreme chemical variation in complex diamonds from George Creek, Colorado: a SIMS study of nitrogen abundance and carbon isotope composition. Mineralogical Magazine, 63, 857-878.
Frank, F.C. (1959). Diamonds and deep fluids in the upper mantle. In: S.K. Runcorn (Editor). The application of modern physics to the Earth and planetary interiors, Wiley: New York, U.S.A., 247-250

Gasparik. T. (1985). Experimental study of subsolidus phase relations and mixing properties of pyroxene and plagioclase in the system $\mathrm{Na}_{2} \mathrm{O} \cdot \mathrm{CaO}$. $\mathrm{Al}_{2} \mathrm{O}_{5}-\mathrm{SiO}_{2}$. Contributions to Mineralogy and Petrology: 89, 346-357.

Good, N. (1997). Tectonic evolution and structural controls on the fluid flow along the Thabazimbi-Murchinson lineament, northern Transvaal. South Africa. Unpublisbed Pb D tbesis, Uniersity of Cape Toun, Soutb Africa. $951 \mathrm{pp}$.

Good, N. and de Wit, M.J. (1997). The Thabazimbi-Murchinson lineament of the Kaapvaal craton, South Africa: 2700 Ma of episolic deformation. Journal of the Geological Society: London, 154, 93-97.

Griffin. W.L., Jaques, A.L., Ryan, C.G., Cousens, D.R. and Suter, G.F. (1988). Conditions of diamond growth: A proton microprobe study of inclusions in West Australian diamonds. Contributions to Mineralogy and Petrology: 99. $143-158$

Gurney, J. J. (1989). Diamonds, In: J. Ross, A.l. Jaques, J. Ferguson, D.H. Green, S.Y. OReilly, R.V. Danchin, A.J.A Janse (Editors), Kimberlites and Related Rocks, Volume 2. Their Mantle/Crust Setting. Diamonds and Diamond Exploration. Geological Society of Australia, Special Publication. Blackuell Scientific, Melbourne, Australia, 14, 935-965.

Gurney. J.J., Jakob, W.R.O. and Dawson, J.13. (1979a). Megacrysts from the Monastery kimberlite pipe, South Africa. In: F.R. Boyd and H.O.A. Meyer (Editors), The Mantle Sample: Inclusions in Kimberlites and Other Volcanics, American Geopbysical Union, 227-243.

Gurney, J.J., Harris, J.W., and Rickard, R.S. (1979b). Silicate and oxide inclusions in diamonds from the Finsch kimberlite pipe. In: F.R. Boyd and H.O.A. Meyer (Editors). The Mante Sample: Inclusions in Kimlerlites and Other Volcanics, American Geoplysical Union, 1-15.

Gurney, J.J., Harris, J.W.. Rickard, R.S. and Moore, R.O. (1985). Inclusions in Premier mine diamonds. Transactions of the Geological Soctety of Soutb Africa, 88, 301-310.

Haggerty, S.E. (1986). Diamond genesis in a multiply constrained model. Nature, 320, 31-38.

Harlow, G.E. (1992). Potassium clinopyroxene at high pressure. Abstract Geological Society of America, Anmual meeting. Session 48-A129.

Hatton, C.J. (1978). The geochemistry and origin of xenoliths from the Roberts Victor mine. Unpublisbed Pb.D. Thesis, Unitersity of Cape Toun, Soutb Africa. 179pp.

Helmstaedt, H. and Doig, R. (1975). Eclogite nodules from kimberlite pipes of the Colorado Plateau - samples of Franciscan-type oceanic lithosphere. Pbysics and Cbemistry of the Earth, 9, 95-111.

Helmstaedt, H. and Schulze, D.J., (1989). South African kimberlites and their mantle sample: Implications for Archean tectonics and lithosphere evolution. In: J. Ross, A.L. Jaques, J. Ferguson, D.H. Green, S.Y. O'Reilly, R.V. Danchin, A.J.A Janse. (Editors) Kimberlites and Related Recks, Volume 1.Their Composition, Occurrence, Origin and Emplacement. Geological Socicty of Australia, Special Publication, Blackuell Scientific, Melbourne, Australia, 14, 935-965.

lloffmann, A.W. and White, W.M. (1982). Mantle plumes from sublucted oceanic crust. Eartb and Planetary Science Letters, 57, 421-436.

Ireland, T.R. Rudnick, R.L. and Spetsius, Z. (1999). Trace elements in diamond inclusions from eclogites reveal link to Archean granites. Eartb and Plametany Science Letters, 128, 199-213.

Jagoutz. E.. Dawson, J.B. Hoernes, S., Spettel, B. and Wanke, H. (198i). Anorthositic oceanic crust in the Archaean. Extended Abstracts, 15th Lunar and Planetan Science Conference, Houston, U.S.A., 395-396.

Jahn, B., Grau, G. and Glikson, A.Y. (1982). Komatiites of the Onverwacht group, South Africa: REF geochemistry, $\mathrm{Sm} / \mathrm{Nd}$ age and mantle evolution. Contributions to .Mineralogy and Petrology: 80, 25-40.

Jarikov, V.A., Ishbulatov, R.A. and Chudinovskih, L.T. (1984). The eclogitic barrier and clinopyroxenes of high pressure. Geologiya $t$ Geofizika.. 12. 54, (in Russian).

Keller, R.A., Taylor, L.A., Snyder, G.A., Sololev, V.N., Carlson, W.D., Bezborodov, S.M. and Sobolev, N.V. (1999). Detailed pull-apart of a diamondiferous eclogite xenolith: implications for mantle processes during diamond genesis, In: J.J. Gurney, J.L. Gurney, M.D. Pascoe and S.H. Richardson (Editors), Proceedings of the $7 t b$ International Kimberlite Conference, Red Roof Design. Cape Toun, Soutb Africa, 1, 397-402.

Kesson, S.E. and Ringwood, A.E. (1989). Slab-mantle interactions, 2. The 
formation of diamonds. Chemical Geology: 78, 97-118.

Kirkley, M.B., Gurney, J.J., Otter, M.I., Hill, S.J. and Daniels, L.R.M. (1991). The application of $\mathrm{C}$ isotope measurments to the identification of the sources of $\mathrm{C}$ in diamonds. Applied Geocbemistry: 6, $+17-494$.

Kramers, J.D. (1979). Lead, uranium, strontium. potassium and rubidium in inclusion-bearing diamonds and mantle-derived xenoliths from southern Africa. Eartb and Planetary Science Letten, 42. 58-70.

Krogh, E.J. (1988). The garnet-clinopyroxene Fe-Nlg geothermometer - a reinterpretation of existing experimental data. Contributions to .Mineralogy and Petrologv: 99, 44-48.

Lappin. M.A. (1978). The evolution of a grospydite from the Rolerts Victor mine, South Africa. Contributions to Aineralogy and Petrologs: 66. $229 \cdot 2+1$.

Le Rocx. A.P., Dick, H.J.B., Gulen, L., Reid, A.M. and Frlank, A.J. (1987). Local and regional heterogeneity in MORB from the Mid-Atlantic Ridge between 54. $4^{\mathrm{vs}}$ and $51^{\mathrm{v}} \mathrm{s}$ : Evidence for geochemical enrichment. Geochimica el Casmochimica Acta. 51. 511.555

Le Roex, A.P., Dick. H.J.B. and Fisher, R.I. (1989). Petrology and geochemistry of MORB from $25^{\circ} \mathrm{E}$ to $16^{\circ} \mathrm{E}$ along the southwest Indian Ridge: Evidence for contrasting styles of mantle enrichment. Journal of Petrologv: 30, 947-986.

MacGregor, I.D. and Manton. W.I. (1986). Roberts Victor eclogites: Ancient oceanic crust. Journal of Geophysical Research. 91, 14063-14079.

McCandless, T.E. and Gurney, J.J. (1989)). Sodium in garnet and potassium in clinopyroxene: criteria for classifying mantle eclogites, $I n$ J. Ross, A.L. Jaques, J. Ferguson, D.H. Green, S.Y. O'Reilly, R.V. Danchin, A.J.A Janse (Editors) Kimberlites and Related Rocks, Volume 2. Their Mantle/Crust Setting. Diamonds and Diamond Exploration. Geological Soctety of Australia, Special Publication Blackuell Sctentific, Mellourne, Australia, 14, $827-832$.

Mendelssohn, M. and Milledge, H.J. (1995). Geologically significant information from routine analysis of the mid-infrared spectra of diamonds. International Geology Retieu, 37. 95-110

Menzies, A.H., Carlson, R.W., Shirey, S.B. and Gurney, J.J. (2003). Re-Os systematics of diamond-|xearing eclogites from the Newlands kimberlite. Litbos, 71, 323-336.

Meyer, H.O.A. (1985). Genesis of diamond: a mantle saga. American . Mineralogist, 70, 34+-355

Meyer, P.S., Dick, H.J.B. and Thompson, G. (1989). Cumulate gabbros from the Southwest Indian Ridge $54^{\circ} \mathrm{S}-71^{\circ} 6 \mathrm{E}$ : Implications for magmatic processes at a slow spreading ridge. Contributions to Mtineralogy and Petrology: 103, 44-63.

Navon, O. (1999). Diamond formation in the earth's mantle, In: J.J. Gurney, J.L. Gurney, Pascoe M.D., and S.H. Richardson (Editors), Proceedings of the $7 \mathrm{lb}$ International Kimberlite Conference. Red Roof Design. Cafe Toun. Soutb Africa, 2, 58i-604.

Otter, M.L. and Gurney, J.J. (1989). Mineral inclusions in diamonds from the Sloan diatremes, Colorado-Wyoming State line kimberlite district, North America. In: J. Ross, A.L. Jaques, J. Ferguson, D.H. Green, S.Y. OReilly, R.V. Danchin, A.J.A Janse (Editors), Kimberlites and Related Rocks, Volume 2. Their Mantle/Crust Setting. Diamonds and Diamond Exploration. Gerlogical Society of Australia, Special Publication Blackuell Scientific. Melbourne, Australia, 14, 10-12-1053.

Parman. S.W.. Dann. J.C., Grove, T.L. and de Wit. M.J. (1997). Emplacement conditions of komatiite magmas from the 3.49 Ga Komati formation. Barberton greenstone belt. South Africa. Earth and Planetary Science Letters, 150, 303-323.

Pearson, D.G., Snyder, G.A., Shirey, S.B., Taylor, L.A., Carlson, R.W. and Sobolev, N.V. (1995). Archaean Re-Os age for Siberian eclogites and constraints on Archacean tectonics. Nature, 374, 711-713.

Polat. A., Kerrich, R. and Wyman. D.A. (1999). Geochemical diversity in oceanic komatiites and basalts from the late Archatean Wawa greenstone belt, Canada: Trace element and Nd isotope evidemce for a heterogeneous mantle. Precambrian Researcb, 94, 139-173

Richardson, S.H., Gurney, J.J., Erlank, A.J. and Harris, J.W. (1984). Origin of diamonds in old enriched mantle. Nature, 310, 198-202.

Richardson, S.H., Shirey, S.B., Harris, J.W. and Carlson, R. W. (2001). Archean subduction recorded by Re-Os isotopes in eclogitic sulfide inclusions in Kimberley diamonds. Eartb and Planctary science letters. 191. 257-266.

Ringwood, A.E. (1982). Phase transformations and differentiation in subducted lithosphere: Implications for mantle dynamics, basalt genesis. and crustal evolution. Journal of Geologs: 90, 611-613.

Rudnick, R.L. (1995). Nature and composition of the continental crust: A lower crustal perspective. Rerieus in Geophysics, 33. 267-300.

Schulze, D.J., Valley, J.W. and Spicuzza, M.J. (2000). Coesite eclogites from the Roberts Victor kimberlite, South Africa. Lithos, 54. 23-32.

Seal. M. (1965). Structure in diamonds as revealed by etching. American Mineralogist, 50, 105-123.

Shee, S. R. (1978). The mineral chemistry of xenoliths from the Orapa pipe. Botswana. Lupublished I/Sc. thesis, Unitersity of Cafe Toun. South Africa. $1.8 \mathrm{pp}$.

Silver, P.G. Gao, S.S. and Liu, K.H. (2001). Mantle deformation beneath southern Africa. Geophysical Research Lethex; 28, 2493-2496.

Smyth. J.R. (1980). Cation vacancies and the crystal chemistry of breakdown reactions in kimberlitic omphacites. American . Hineralogist, 65. 1185-1191. Smyth, J.R. and Hatton, C.J. (1977). A coesite-sanidine grospydite from the Roberts Victor kimberlite. Eartb and Planetary Science Letters. 34, 28i-288. Smyth, J.R., Caporuscio, F.A.. and McCormick. T.C. (1989). Mantle eclogites: Evidence for igneous fractionation in the mantle. Eartb and Planetary Science Letters, 93, 133-1+1.

Sololev, N.V. (1983). Parageneses of the diamonds and the problems of mineral formation in deep seated conditions. Zapiski lsesoyzazuogo Mineralogitclueskogo Obsbtchestica, 112, 389-397

Sobolev, N.V., Yefimova, E.S., Lavretivev, Yu.G. and Sololev, F.V. (1981) Dominant calc-silicate association of crystalline inclusions in placer diamonds from southeastern Australia. Doklady Akudemu Nauk S.S.S.R. 247. 148-153.

Taylor, W.R., Jaques, A.L. and Ridd, M. (1990). Nitrogen-defect aggregation characteristics of some Australasian diamonds: Time-temperature constraints on the source regions of pipe and alluvial diamonds. American Mineralogist, 75, 1290-1310.

Taylor, L.A., Milledge, HJ., Bulanova, G.P., Snyder, G.A. and keller, R.A. (1998). Metasomatic eclogitic diamond growth: evidence from multiple diamond inclusions. International Geology Retiete; 40, 663-676.

van Heerden, L.A., Boyd, S.R., Milledge, H.J. and Pillinger, C.T. (1995). The carbon- and nitrogen-isotope characteristics of the Argyle and Ellendale diamonds, western Australia. International Geology Recteu: 37. 39-50.

Vinnik, L.P., Green, R.W.E. and Nicolaysen, L.O. (1995). Recent deformations on the deep continental roots in Southern Africa. Nature, 375. 50-52.

Westerlund, K.J., Gurney, J.J., Carlson, R.W., Shirey, S.B.. Hauri. E.H. and Richardson. S.H. (200-1) A metasomatic origin for late Archaean eclogitic diamonds: Implications from internal morphology of diamonds and Re-Os and $\mathrm{S}$ isotope characteristics of their sulfide inclusions from the late Jurassic Klipspringer kimberlites. Soutb African fournal of Geologs: 107. 119-130. Wood, B.J. and Henderson, C.M.B. (1978). Compositions and unit-cell parameters of synthetic non-stoichiometric tschermakitic clinopyroxenes. American Mineralogist, 63, 66-72.

Wooks. G.S. (1986). Platelets and the infrared absorption of type la diamonds. Procecdings of the Koyal Society: London, 407, 219-238.

Zezin. R.B., Saparin, G.V., Smirnova, F.P., Obyden, S.K. and Chukichev, M.V (1990). Cathodoluminescence of natural diamonds from Jakutian deposits. Scamning, 12, 326-333.

Editorial handling: S. Richardson 
Copyright of South African Journal of Geology is the property of Geological Society of South Africa and its content may not be copied or emailed to multiple sites or posted to a listserv without the copyright holder's express written permission. However, users may print, download, or email articles for individual use. 